\title{
Geostatistical Studies of Space-Temporal Variation in Selected Quality Parameters in Klodzko Water Supply System (SW Part of Poland)
}

\author{
Barbara Namysłowska-Wilczyńska \\ Faculty of Civil Engineering, Wrocław University of Technology, Wybrzeże Wyspiańskiego 27, Wrocław 50-370, Poland
}

\begin{abstract}
Selected results of research connected with the development of a (3D) geostatistical hydrogeochemical model of the Klodzko city area, dedicated to the spatial and time variation in the quality parameters in the Klodzko water supply system (SW part of Poland) have been presented. The research covers the period 2007-2011. Spatial analyses of the variation in three quality parameters, i.e. Fe iron $\left(\mathrm{g} / \mathrm{m}^{3}\right)$ content, Mn manganese $\left(\mathrm{g} / \mathrm{m}^{3}\right)$ content and $\mathrm{NH}_{4}{ }^{+}$ammonium ion $\left(\mathrm{g} / \mathrm{m}^{3}\right)$ content, were carried out. Spatial and time variation in the parameters was analyzed on the basis of the data (2007-2011). The input for the studies was the chemical determinations of the quality parameters of water samples taken in the Klodzko water supply system area (also treated water) in different periods of time. These data were subjected to spatial analyses using geostatistical methods. The parameters of the assumed theoretical models of directional semivariograms functions of the studied regionalized variables, were used in the ordinary (block) kriging estimation. Generally, the behaviour of the quality parameters in the Klodzko water supply system has been found to vary in space and time. Thanks to the multivariate spatial analyses some regularities in the variation in the water supply system in the Klodzko city area have been identified. In the considered time interval, the shapes of the directional Fe iron content semivariogram show a tendency to vary periodically. The courses of the directional semivariograms of $\mathrm{Mn}$ manganese content and $\mathrm{NH}_{4}^{+}$ammonium ion content show some tendencies towards directional variation over the passing years. There are visible distinct increasing trends of variability for $\mathrm{Mn}$ content and stronger variation are observed for $\mathrm{NH}_{4}{ }^{+}$ion content. The kriging estimation results were used to determine the levels of elevated values $Z^{*}$ of the water quality parameters in the years 2007-2011 and to forecast these values for the years 2012-2014. The maximum values $Z^{*}$ of the quality parameters were stated for the years: 2007, $2008-2009$ and 2012 (the decreasing trend in Fe iron content averages $Z^{*}$ variation towards the year 2012, the increasing trend in Mn content averages $Z^{*}$ variation towards the year 2012 and the increasing trend in $\mathrm{NH}_{4}{ }^{+}$ion content averages $Z^{*}$ variation towards the years 2008-2009 and then the decreasing trend towards the year 2012).
\end{abstract}

Key words: Treated water, water supply system, quality parameters, spatio-temporal variation, geostatistics, directional semivariogram, ordinary kriging.

\section{Introduction}

The quality of water in the urban water supply system is vitally important since it affects the health of the population. Generally, the farther below the permissible levels the water quality parameters are, the better our health (which is an invaluable asset).

The objective of this study is the area-time variation in the quality parameters of the water in the water supply system in the town of Klodzko (SW part of Poland) in the years 2007-2011. The subject of spatial estimations was the variation in the main three quality parameters, i.e. iron (Fe) content, manganese (Mn) content and ammonium ion $\left(\mathrm{NH}_{4}{ }^{+}\right)$content, in treated water and of the water in the water supply network in the Klodzko town area. Data on network water quality were made available to the author by the Klodzko Water Board in connection with her research carried

Corresponding author: Barbara Namysłowska-Wilczyńska, Dr. Prof., research field: geology and geostatistics. E-mail: Barbara.Namyslowska-Wilczynska@pwr.edu.pl. 
out in the years $2011-2012^{1}$.

The results of previous spatial (3D) analyses of the variation in $\mathrm{Fe}$ content and $\mathrm{Mn}$ content in underground water in the Klodzko water intake area and of the oxidation capacity of the water, i.e. evaluation of basic statistics and estimation of underground water selected quality parameters by means of ordinary kriging were reported in [1-4]. A hydrogeochemical assessment of the environments characteristic of river valleys, for underground water abstraction purposes in the Klodzkoregion was presented in, e.g., Refs. [1-6].

The present paper is another work dealing with the quality of water in the Klodzko water supply system, focusing on the variation in the basic quality parameters. The spatial analyses are based on the results of chemical determinations of the network water for the years 2007-2011 and of the treated water for the years 2008-2011 [1]. Databases, containing original data on coordinates $X, Y$ - (latitude, longitude) and $Z$ (time-years) and on regionalized variables, i.e. the water quality parameters in the Klodzko water supply system (also treated water), were elaborated.

The results of the estimation of treated water and raw (mixed) water determinations carried out in the years 2008-2011 are reported. Also the results of assessments of the basic parameters of the quality of water in the water supply network carried out in the years 2007-2011 are presented.

Then spatial analyses, i.e. 3D geostatistical studies ${ }^{2}$ of the quality parameters of the network water and the treated water, were carried out. The analyses were based on the directional variogram function and the ordinary kriging technique (in its block and point

\footnotetext{
${ }^{1}$ The research was carried out as part the National Centre for Research \& Development grant No. N09-0036-10/2011, entitled "the technology of the biochemical remediation and storage of surface waters in underground hydrogeological structures for municipal water intakes in river valleys" funded by the Ministry of Science and Higher Education in Warsaw. Research task 3 entitled "identification and hydrogeochemical models of the Klodzko Drainage Area (2011-2012)" (2012) [1]. ${ }^{2}$ The geostatistical studies were conducted using statistical software package ISATIS (the Isatis version 2015) made by Geovariances Firm, Avon Cedex-Fontainebleau, France;
}

versions $)^{3}$. The theoretical basis of the methods is presented in, e.g., Refs. [7-10].

An analysis of the directional semivariograms (D-90) of the quality parameters of the network water and the treated water in the Klodzko area was carried using directional variogram function $\gamma(h)$. The aim of the structural analysis was to characterize the existing variation tendencies and to get an idea of the character and degree of the changes in the values of semivariogram function $\gamma(h)$ in the years 2007-2011 and 2008-2011.

Then the empirical directional semivariograms (D-90) were subjected to modelling using theoretical analytical functions. Their agreement with the adopted theoretical models was examined using the cross-validation procedure and ordinary point kriging.

Knowing the values of the geostatistical parameters of the theoretical models it was possible to estimate averages $Z^{*}$ of the investigated parameters of the water in the Klodzko town water supply network in the time intervals mentioned above, using the ordinary block kriging technique.

\section{Evaluation of Basic Statistics of Treated (First Point of Water Consumption) Water Quality Parameters for Years 2007-2011}

According to the Regulations of the Minister of Health the amount of iron and manganese in the water can not be greater, than respectively $0.2 \mathrm{gFe} / \mathrm{m}^{3}$ and $0.05 \mathrm{gMn} / \mathrm{m}^{3}[5,11-13]$.

Iron $\mathrm{Fe}$ presents in the water in the form of $\mathrm{Fe}^{+2}$ compounds of di- and trivalent $\mathrm{Fe}^{+3}$, respectively $\mathrm{Fe}$ (II) and Fe (III) [14]. Under aerobic conditions, e.g. in surface waters prevail compounds of $\mathrm{Fe}$ (III). Hydrolyze - under the influence of the water

\footnotetext{
${ }^{3}$ Some results of the studies of spatio-temporal variation of iron $(\mathrm{Fe})$, manganese $(\mathrm{Mn})$ and ammonium ion $\left(\mathrm{NH}_{4}{ }^{+}\right)$content in treated water and of the water in the water supply network in the Klodzko were presented during EGU 2015 European Geosciences Union-General Assembly Austria Center Vienna (12-17 April 15) at the Session Hydroinformatics: geo-statistics for space-temporal analysis of hydrological events and environmental problems (April 13, 2015) [15].
} 
precipitated as a solid. The concentration of the compounds of the Fe present in the dissolved form is thus usually small. In the deep-sea, which under anaerobic conditions dominate $\mathrm{Fe}$ in the form of ions dissolved in the water divalent $\mathrm{Fe}^{+2}$ (II). Their number can range from trace values to several $\mathrm{gFe} / \mathrm{m}^{3} . \mathrm{Mn}$ is present in the deep-sea in the form of soluble compounds of divalent $\mathrm{Mn}^{+2}$ (II). $\mathrm{Mn}$ is very often accompanied compounds of $\mathrm{Fe}$, but it is usually much less - up to $10 \mathrm{gMn} / \mathrm{m}^{3}$. Fe removal is based on the oxidation of all the soluble forms of two-value $(+2)$ $\mathrm{Fe}^{+2}$ (II) to water-insoluble trivalent form $\mathrm{Fe}^{+3}$ (III), followed by the removal of the water formed compounds of Fe (III). Removal takes place by means of filtration and adsorption on appropriately selected fields. Demanganization extends in a similar way, except that the compounds of the divalent $\mathrm{Mn}^{+2}$ (II) are oxidized to form tetravalent $\mathrm{Mn}^{+4}$ (IV) [14]. Creation by Mn compounds, however, are more durable and harder to remove.

In the presented case, i.e. study for the region of Klodzko, sources of the increased contents of $\mathrm{Fe}$ and $\mathrm{Mn}$ are connected first of all with agriculture, i.e. farming, improper fertilization of agricultural land and also caused by the factors of geochemical origin (rock-base in Klodzko water intake area) [5, 6].

The Fe and Mn compounds from the rocks and the soil are leached into the deep waters. The iron $(\mathrm{Fe})$ may come from metallurgical wastes while the Mn may originate from the mining, smelting, ceramic and artificial fertilizer industries.

The filtered impurities should be periodically removed by washing the bed in a direction opposite to the normal flow. Rinsing must be intense to lift the bed and clean thoroughly.

The minimum required water flow by scrubbing is usually 1.5 times to two times greater than during filtering. Washings discharged into drains. The choice of the filter bed and all other treatment elements is always an individual. Consideration is given to the chemical composition of water: concentrations of $\mathrm{Fe}$ and $\mathrm{Mn}$, the form in which they appear, $\mathrm{pH}$, oxygen and carbon dioxide, the presence of hydrogen sulfide or ammonia.

It is important that they be water quality after treatment and how much she needed. Not without significance installation parameters and type of hydrovor (type of WDS).

Basic information on the water treatment technology used in the Klodzko town is provided in, e.g., Ref. [11, 14-16].

A modern water treatment plant with a capacity of about $9,000 \mathrm{~m}^{3} / 24 \mathrm{~h}$ was built in Klodzko in the years 1996-1999. Water from the intakes is fed into the aeration tower from where it gravitationally flows through reaction tanks, filters and a clean water tank. The function of the tower is to aerate the water and separate carbon dioxide $\left(\mathrm{CO}_{2}\right)$, hydrogen sulphide $\left(\mathrm{H}_{2} \mathrm{~S}\right)$, other volatile substances and low-molecular-mass organic compounds from it. Atmospheric oxygen introduced into the water oxidizes iron $(\mathrm{Fe})$ and manganese $(\mathrm{Mn})$ compounds, which improves the taste and smell of the water. The forming $\mathrm{Fe}$ and $\mathrm{Mn}$ compounds are captured as sediment by sand filters. The filters, made of stainless steel, are characterized by high quality of workmanship, simple design, minimal service requirements, continuous operation, high filtration efficiency and low bed-washing water consumption. After filtration an aqueous solution of chlorine dioxide $\left(\mathrm{ClO}_{2}\right)$ is added to the water, acting bactericidally and protecting the water in the urban network distribution system. Chlorine dioxide is odourless, prevents deposit build-up in water installations, kills bacteria, leaves no harmful residue and does not require neutralization. Pure water is collected in a $1,000 \mathrm{~m}^{3}$ capacity tank and then pumped by a pumping station to the urban network. The quality of the treated water is controlled by the water company and independent water quality laboratories.

Table 1 shows the basic statistics for the treated FPWC (first point of water consumption) water quality parameters in the Klodzko town area. The estimates are 
based on the results of chemical analyses of the treated water carried out in the years 2007-2011. In that period chemical determinations of different quality parameters, i.e. iron $(\mathrm{Fe})$ content, manganese $(\mathrm{Mn})$ content, ammonium ion $\left(\mathrm{NH}_{4}{ }^{+}\right)$content, heavy metals $(\mathrm{Cu}, \mathrm{Cd}, \mathrm{Pb}, \mathrm{Ni}, \mathrm{Cr}$, and $\mathrm{Hg})$ content, oxidation capacity and TOC (total organic carbon) content of treated (FPWC) water were carried out 16 times.

From among the studied parameters, lead $(\mathrm{Pb})$ content, ammonium ion $\left(\mathrm{NH}_{4}{ }^{+}\right)$content and copper $(\mathrm{Cu})$ content show the strongest (extreme and very high) variation, reflected in the highest values of coefficients $V$ (Table 1). Also TOC (total organic carbon), cadmium (Cd) content, manganese (Mn) content, oxidation capacity, chromium $(\mathrm{Cr})$ content and iron $(\mathrm{Fe})$ content were found to vary considerably.

Permissible values of the investigated quality parameters of treated water are as follows:

- content of $\mathrm{Mn}<0.050\left(\mathrm{gMn} / \mathrm{m}^{3}\right)$,

- content of $\mathrm{Fe}<0.200\left(\mathrm{gFe} / \mathrm{m}^{3}\right)$,

- content of $\mathrm{NH}_{4}{ }^{+}$ion $<0.500\left(\mathrm{gNH}_{4}{ }^{+} / \mathrm{m}^{3}\right)$,

- content of overall organic coal $\mathrm{C}(\mathrm{OWO})-(5$ $\left.\mathrm{gC} / \mathrm{m}^{3}\right)$,

- oxidizability $\mathrm{O}_{2}-5\left(\mathrm{gO}_{2} / \mathrm{m}^{3}\right)$,

- content of $\mathrm{Pb}-0.025\left(\mathrm{gPb} / \mathrm{m}^{3}\right)$,

- content of $\mathrm{Cd}-0.005\left(\mathrm{gCd} / \mathrm{m}^{3}\right)$,

- content of $\mathrm{Cu}-2.000\left(\mathrm{gCu} / \mathrm{m}^{3}\right)$,
- content of $\mathrm{Hg}-0.001\left(\mathrm{gHg} / \mathrm{m}^{3}\right)$,

- content of $\mathrm{Cr}-0.050\left(\mathrm{gCr} / \mathrm{m}^{3}\right)$,

- content of $\mathrm{Ni}-0.020\left(\mathrm{gNi} / \mathrm{m}^{3}\right)$,

- content of $\mathrm{Ag}<0.010\left(\mathrm{gAg} / \mathrm{m}^{3}\right)$.

From among the 11 analyzed parameters, three basic quality parameters- $\mathrm{Fe}$ content, $\mathrm{Mn}$ content and $\mathrm{NH}_{4}{ }^{+}$ content of the treated water in the Klodzko town area did not exceed the allowable values (Table 1). Only the maximum cadmium $(\mathrm{Cd})$ content and the minimum, maximum and average mercury $(\mathrm{Hg})$ content reach the level allowable for these elements (Table 1).

The coefficients of the correlation between the original values $Z$ of the analyzed quality parameter of treated water indicate no correlation or weak negative correlation between them:

$$
\begin{aligned}
& \mathrm{Fe} / \mathrm{Mn}-0.1273, \\
& \mathrm{Mn} / \mathrm{NH}_{4}{ }^{+}-0.3133, \\
& \mathrm{Fe} / \mathrm{NH}_{4}{ }^{+}-0.0543 .
\end{aligned}
$$

\section{Evaluation of Basic Statistics of Water Quality Parameters in Water Supply System (Years 2007-2011)}

Estimates of the basic statistics of the water quality parameters in the Klodzko town water supply system in the years 2007-2011 are presented in Table 2. The results show that the maximum values of the two

\begin{tabular}{|c|c|c|c|c|c|c|}
\hline Analyzed parameter & $\begin{array}{l}\text { Sample } \\
\text { size } \\
n \\
\end{array}$ & $\begin{array}{l}\text { Min. value } \\
X_{\min } \\
\left(\mathrm{g} / \mathrm{m}^{3}\right) \\
\end{array}$ & $\begin{array}{l}\text { Max. value } \\
X_{\max } \\
\left(\mathrm{g} / \mathrm{m}^{3}\right) \\
\end{array}$ & $\begin{array}{l}\text { Average value } \\
X \\
\left(\mathrm{~g} / \mathrm{m}^{3}\right)\end{array}$ & $\begin{array}{l}\text { St. deviation } \\
S \\
\left(\mathrm{~g} / \mathrm{m}^{3}\right) \\
\end{array}$ & $\begin{array}{l}\text { Variation coefficient } \\
V \\
(\%) \\
\end{array}$ \\
\hline Content of $\mathrm{Fe}$ iron & 16 & 0.0005 & 0.1300 & 0.0566 & 0.0265 & 46.85 \\
\hline Content of Mn manganese & 16 & 0.0010 & 0.0440 & 0.0137 & 0.0093 & 67.86 \\
\hline $\begin{array}{l}\text { Content of } \mathrm{NH}_{4}^{+} \\
\text {ammonium ion }\end{array}$ & 16 & 0.0130 & 0.2900 & 0.0666 & 0.0682 & 102.40 \\
\hline Content of $\mathrm{Cu}$ copper & 8 & 0.0005 & 0.0030 & 0.0008 & 0.0008 & 101.76 \\
\hline Content of $\mathrm{Hg}$ mercury & 8 & 0.0030 & 0.0040 & 0.0039 & 0.0003 & 8.53 \\
\hline Content of Cd cadmium & 8 & 0.0005 & 0.0090 & 0.0031 & 0.0024 & 79.33 \\
\hline Content of Ni nickel & 2 & 0.0010 & 0.0020 & 0.0015 & 0.0005 & 33.33 \\
\hline Content of $\mathrm{Cr}$ chromium & 8 & 0.0010 & 0.0110 & 0.0051 & 0.0026 & 50.16 \\
\hline Content of $\mathrm{Pb}$ lead & 9 & 0.0003 & 0.0040 & 0.0011 & 0.0015 & 133.48 \\
\hline Oxidizablity $\mathrm{O}_{2}$ & 9 & 0.0005 & 0.0100 & 0.0042 & 0.0023 & 56.00 \\
\hline $\begin{array}{l}\text { Content of overall organic } \\
\text { coal C (OWO) }\end{array}$ & 9 & 0.0005 & 4.4000 & 1.7769 & 1.5888 & 89.41 \\
\hline
\end{tabular}
considered parameters, i.e. Fe content and Mn content,

Table 1 Basic statistics of quality parameters of treated (FPWC) water for years 2007-2011. 
Table 2 Basic statistics of water quality parameters in water supply system in Klodzko town area (years 2007-2011).

\begin{tabular}{lllllll}
\hline $\begin{array}{l}\text { Analyzed } \\
\text { parameter }\end{array}$ & $\begin{array}{l}\text { Sample } \\
\text { size } \\
n\end{array}$ & $\begin{array}{l}\text { Min. value } \\
X_{\min } \\
\left(\mathrm{g} / \mathrm{m}^{3}\right)\end{array}$ & $\begin{array}{l}\text { Max. value } \\
X_{\max } \\
\left(\mathrm{g} / \mathrm{m}^{3}\right)\end{array}$ & $\begin{array}{l}\text { Average value } \\
\left(\mathrm{g} / \mathrm{m}^{3}\right)\end{array}$ & $\begin{array}{l}\text { St. deviation } \\
\left.\text { ( } / \mathrm{m}^{3}\right)\end{array}$ & $\begin{array}{l}\text { Variation coefficient } \\
V \\
(\%)\end{array}$ \\
\hline $\begin{array}{l}\text { Content of iron Fe } \\
\text { Content of manganese Mn }\end{array}$ & 65 & 0.01 & 0.34 & 0.07 & 0.05 & 70.00 \\
$\begin{array}{l}\text { Content of ammonium ion } \\
\mathrm{NH}_{4}^{+}\end{array}$ & 0.00 & 0.12 & 0.02 & 0.02 & 96.00 \\
\hline
\end{tabular}

Table 3 Basic statistics of raw (mixed) water quality parameters for years 2008-2011.

\begin{tabular}{|c|c|c|c|c|c|c|}
\hline Analyzed parameter & $\begin{array}{l}\text { Sample } \\
\text { size } \\
n \\
\end{array}$ & $\begin{array}{l}\text { Min. value } \\
X_{\min } \\
\left(\mathrm{g} / \mathrm{m}^{3}\right) \\
\end{array}$ & $\begin{array}{l}\text { Max. value } \\
X_{\max } \\
\left(\mathrm{g} / \mathrm{m}^{3}\right) \\
\end{array}$ & $\begin{array}{l}\text { Average value } \\
X \\
\left(\mathrm{~g} / \mathrm{m}^{3}\right)\end{array}$ & $\begin{array}{l}\text { St. deviation } \\
S \\
\left(\mathrm{~g} / \mathrm{m}^{3}\right) \\
\end{array}$ & $\begin{array}{l}\text { Variation coefficient } \\
V \\
(\%) \\
\end{array}$ \\
\hline Content of Fe iron & 5 & 0.0220 & 0.2000 & 0.0824 & 0.0610 & 74.09 \\
\hline Content of Mn manganese & 5 & 0.1140 & 0.8400 & 0.3362 & 0.2847 & 84.69 \\
\hline $\begin{array}{l}\text { Content of } \mathrm{NH}_{4}^{+} \\
\text {ammonium ion }\end{array}$ & 5 & 0.0130 & 0.2400 & 0.0732 & 0.0856 & 116.16 \\
\hline Content of $\mathrm{Cu}$ copper & 5 & 0.0000 & 0.0005 & 0.0003 & 0.0002 & 68.89 \\
\hline Content of $\mathrm{Hg}$ mercury & 5 & 0.0005 & 0.0040 & 0.0031 & 0.0014 & 43.76 \\
\hline Content of $\mathrm{Cd}$ cadmium & 5 & 0.0020 & 0.1280 & 0.0276 & 0.0502 & 181.91 \\
\hline Content of Ni nickel & 2 & 0.0010 & 0.0020 & 0.0015 & 0.0005 & 33.33 \\
\hline Content of $\mathrm{Cr}$ chromium & 5 & 0.0040 & 0.0060 & 0.0048 & 0.0007 & 15.59 \\
\hline Content of $\mathrm{Pb}$ lead & 5 & 0.0003 & 0.0009 & 0.0005 & 0.0002 & 43.82 \\
\hline Oxidizability $\mathrm{O}_{2}$ & 5 & 0.0040 & 0.0100 & 0.0064 & 0.0029 & 45.93 \\
\hline $\begin{array}{l}\text { Content Of Overall } \\
\text { organic Coal C (OWO) }\end{array}$ & 5 & 0.2544 & 6.6700 & 3.3449 & 2.3260 & 69.54 \\
\hline
\end{tabular}

exceed the standard, the permissible values (Table 2). The mean value of Mn content reaches the allowable level of this element content in water. Whereas the averages of the other considered water quality parameters, i.e. Fe content and $\mathrm{NH}_{4}{ }^{+}$content were much below the permissible values. The minimum values for the three parameters are close to zero.

High values of variation coefficient $V$ were obtained for the water quality parameters in the water supply system, which were higher for Mn content and $\mathrm{NH}_{4}{ }^{+}$ content. This indicates stronger variation in the values of the two parameters in comparison with the Fe content variation (Table 2).

Permissible values of the investigated quality parameters of water are as follows:

- content of $\mathrm{Mn}<0.050\left(\mathrm{gMn} / \mathrm{m}^{3}\right)$,

- content of $\mathrm{Fe}<0.200\left(\mathrm{gFe} / \mathrm{m}^{3}\right)$,

- content of ammonium ion $\mathrm{NH}_{4}^{+}<0.500$ $\left(\mathrm{gNH}_{4}{ }^{+} / \mathrm{m}^{3}\right)$.

For a comparison the observed values of quality parameters, i.e. Fe content and $\mathrm{Mn}$ content in water supply system and treated water in Wroclaw town amounted to $<0.02\left(\mathrm{gFe} / \mathrm{m}^{3}\right)$ and $<0.005\left(\mathrm{gMn} / \mathrm{m}^{3}\right)$. These results did not exceed the permissible (norm) values of these parameters, i.e. $0.2\left(\mathrm{gFe} / \mathrm{m}^{3}\right)$ and 0.05 $\left(\mathrm{gMn} / \mathrm{m}^{3}\right)$.

The coefficients of the correlation between the original values $Z$ for the three network water quality parameters indicate (as expected) no correlation between them:

$$
\begin{aligned}
& \mathrm{Fe} / \mathrm{Mn}-0.031, \\
& \mathrm{NH}_{4}^{+} / \mathrm{Mn}-0.099, \\
& \mathrm{NH}_{4}^{+} / \mathrm{Fe}-0.0968 .
\end{aligned}
$$

\section{Evaluation of Basic Statistics of Raw (Mixed) Water Quality Parameters (Years 2008-2011)}

The basic statistics of the quality parameters of the raw (mixed) water in the Klodzko town area are shown in Table 3. Data acquired from chemical analyses 
carried out in the years 2008-2011 were used in the evaluation. In that period chemical determinations of different raw (mixed) water quality parameters, e.g. Fe content, $\mathrm{Mn}$ content, ion $\mathrm{NH}_{4}{ }^{+}$content, heavy metals $(\mathrm{Cu}, \mathrm{Cd}, \mathrm{Pb}, \mathrm{Ni}, \mathrm{Cr}$ and $\mathrm{Hg}$ ) content, as well as oxidation capacity and TOC (total organic carbon) content were carried out five times (Table 3 ).

From among the analyzed raw (mixed) water parameters, extreme and very high variation characterized cadmium $\mathrm{Cd}$ content and ammonium ion $\left(\mathrm{NH}_{4}{ }^{+}\right)$content, for which the highest values of coefficient $V$ were obtained (Table 3 ). Also Mn content, $\mathrm{Fe}$ content, $\mathrm{Cu}$ content and TOC (total organic carbon) content were characterized by high variation (Table 3).

Permissible values of the investigated quality parameters of raw-mixed water were given in Tables 1 and 2.

In the raw (mixed) water the minimum, maximum and mean values of $\mathrm{Mn}$ content exceeded the permissible (standard) level of this element (Table 3). Also the maximum and mean values of $\mathrm{Cd}$ content and $\mathrm{Hg}$ content and the maximum TOC (total organic carbon) content exceeded the standard levels. The maximum $\mathrm{Fe}$ content was found to be equal to the standard value for this element.

\section{Analysis of Water Quality Parameter Distribution Histograms}

Then histograms of the distribution of the water quality parameters, i.e. Fe content, Mn content and ammonium ion $\left(\mathrm{NH}_{4}{ }^{+}\right)$content, in the Klodzko town area water supply system were analyzed.

Histograms of the distribution of the water quality parameters: Fe content, Mn content and ammonium ion $\left(\mathrm{NH}_{4}{ }^{+}\right)$content were calculated using water sampling data for the period 2007-2011 (Figs. 1-3).

The histograms of the distribution of the considered parameters are distinctly positively skew and sharp (Figs. 1-3) (Table 4). The histogram of the distribution of $\mathrm{Fe}$ content (Fig. 1) is single-wing while the histogram of $\mathrm{Mn}$ content distribution has a bimodal character (Fig. 2). The histogram of $\mathrm{NH}_{4}{ }^{+}$content is a unimodal (Fig. 3). The histograms of Fe content and ammonium ion $\mathrm{NH}_{4}{ }^{+}$distribution are characterized by the highest kurtosis $\left(g_{2}\right)$. The positive skewness $\left(g_{1}\right)$ of the histograms is in a range of 3.54-3.83 (Fig. 3).

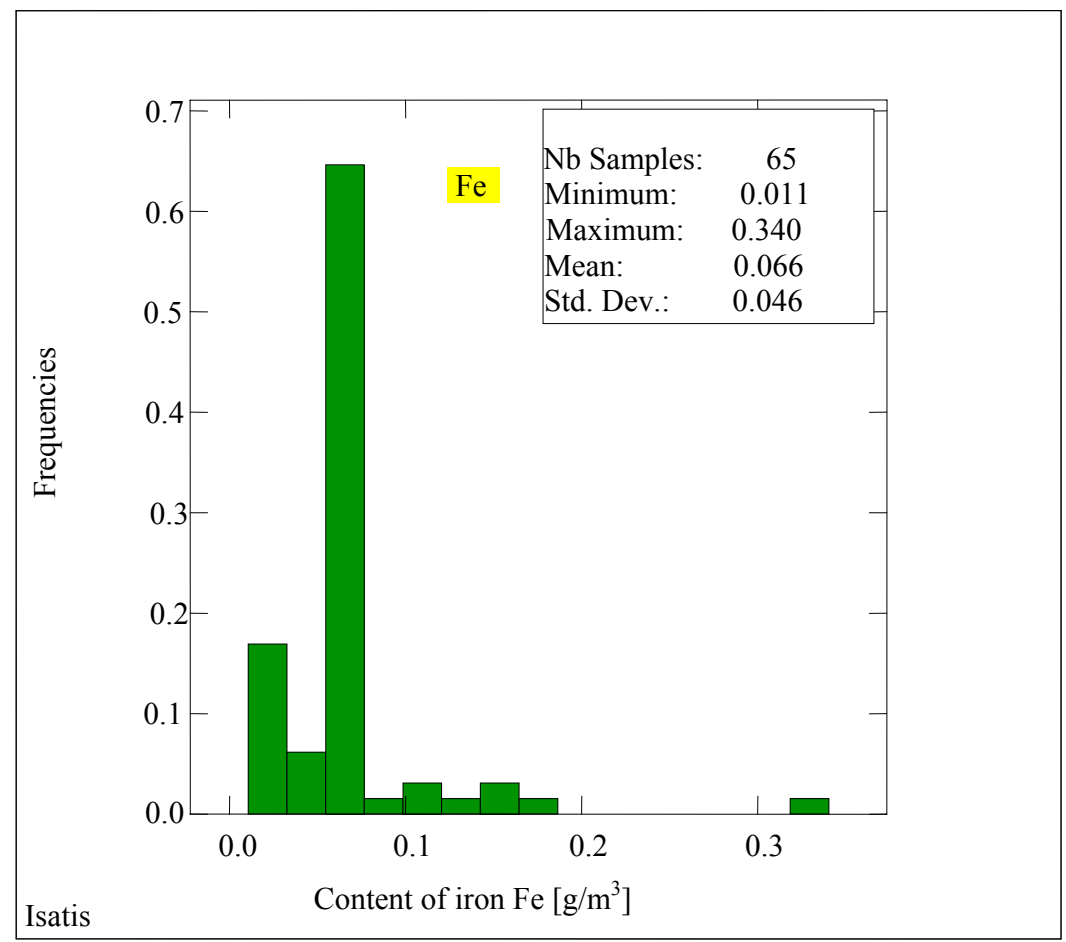

Fig. 1 Histogram of distribution of iron $(\mathrm{Fe})$ content $\left[\mathrm{gFe} / \mathrm{m}^{3}\right]$ in water supply system in Klodzko town area. 
Geostatistical Studies of Space-Temporal Variation in Selected Quality Parameters in Klodzko Water Supply System (SW Part of Poland)

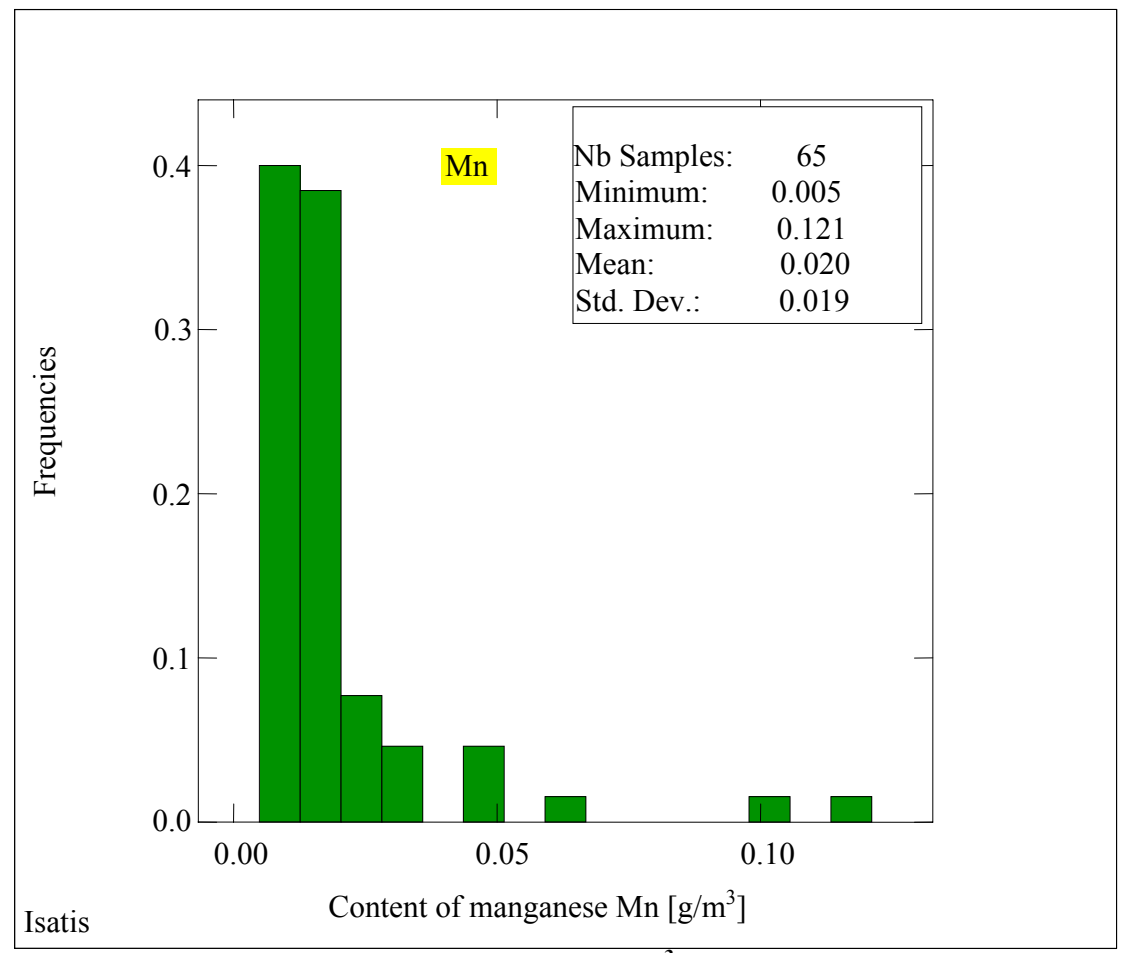

Fig. 2 Histogram of distribution of manganese (Mn) content $\left[\mathrm{gMn} / \mathrm{m}^{3}\right]$ in water supply system in Klodzko town area.

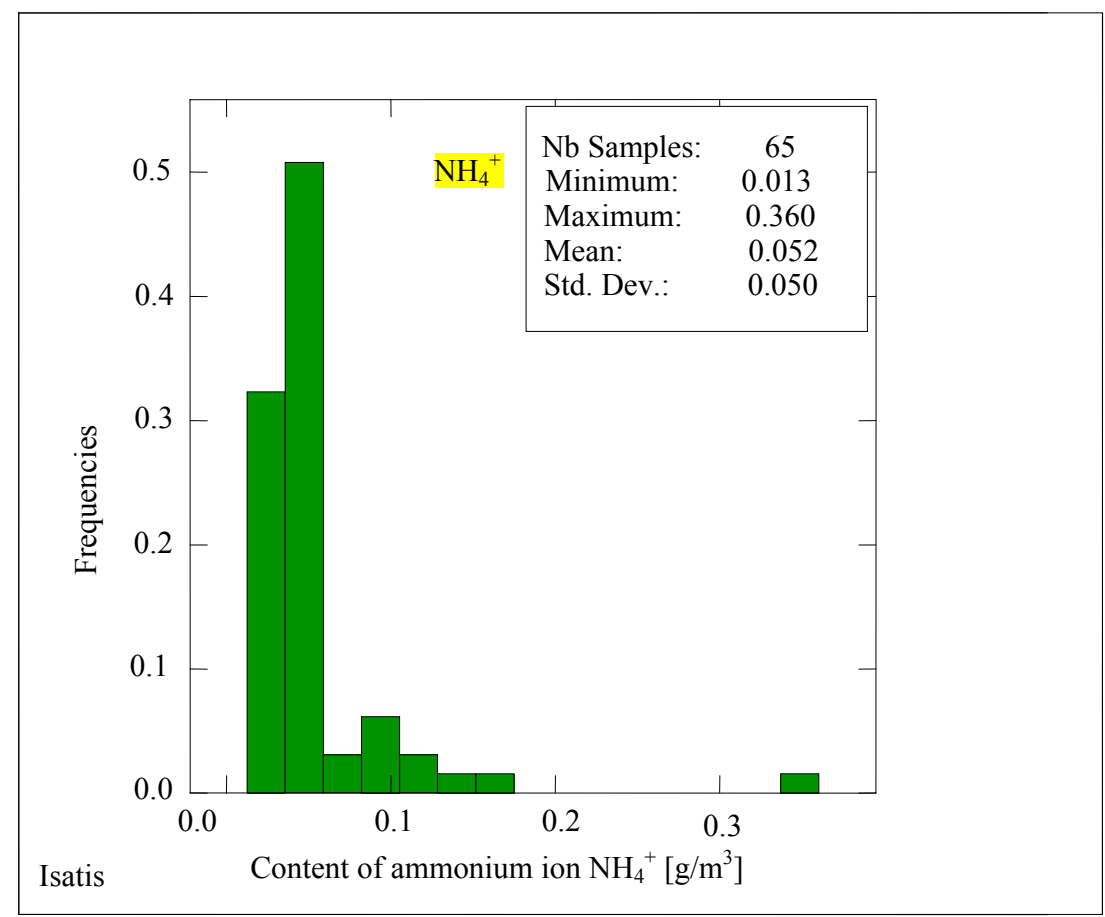

Fig. 3 Histogram of distribution of ammonium ion $\left(\mathrm{NH}_{4}{ }^{+}\right)$content $\left[\mathrm{gNH}_{4}{ }^{+} / \mathrm{m}^{3}\right]$ in water supply system in Klodzko town area.

Table 4 Comparison of skewness $g_{1}$ and kurtosis $g_{2}$ values of histograms showing distribution of water quality parameters (original data) in Klodzko town area water supply system.

\begin{tabular}{lll}
\hline Analyzed parameter & Skewness $g_{1}$ & Kurtosis $g_{2}$ \\
\hline Content of $\mathrm{Fe}$ iron $\left(\mathrm{gFe} / \mathrm{m}^{3}\right)$ & 3.62 & 20.59 \\
Content of $\mathrm{Mn}$ manganese $\left(\mathrm{gMn} / \mathrm{m}^{3}\right)$ & 3.54 & 16.85 \\
Content of $\mathrm{NH}_{4}^{+}$ammonium ion $\left(\mathrm{gNH}_{4}^{+} / \mathrm{m}^{3}\right)$ & 3.83 & 22.84 \\
\hline
\end{tabular}




\section{Analysis of Variograms}

\subsection{Analysis of Directional Semivariograms of Water} Quality Parameters in Klodzko Town Area Water Supply System (Years 2007-2011)

The directional semivariograms (D-90) of Fe content, Mn content and $\mathrm{NH}_{4}{ }^{+}$ion content in the water in the Klodzko water supply system were analyzed. The directional semivariograms (D-90) of the water quality parameters were calculated along the time axis (the years 2007-2011) (Figs. 4-6).

The character and degree of variation of semivariogram function $\gamma(h)$ for the particular quality parameters were analyzed and the differences in the shape of the semivariograms over time were evaluated.

In the analyzed period of time the directional semivariogram (D-90) of Fe content showed a clear tendency towards periodic changes in the values of function $\gamma(h)$ of this parameter, with a noticeable nugget effect $\left(C_{0}\right)$ share in overall variation $C$ (Fig. 4). The shape of this semivariogram could be more precisely represented by a sinusoidal model (e.g. Since Card) than by the adopted spherical model. But this is not possible due to the limitations imposed by the Isatis software.

In the directional semivariogram (D-90) of $\mathrm{Mn}$ content one can observe a rather slow, but consistent, growing tendency in the values of function $\gamma(h)$ of this parameter in the analyzed period (Fig. 5). The semivariogram reveals a very large share of the random component (nugget effect $C_{0}$ ) in overall variation $C$.

The directional semivariogram (D-90) of ammonium ion $\left(\mathrm{NH}_{4}{ }^{+}\right)$content also shows a clearly growing tendency in the values of function $\gamma(h)$ of this parameter over the years 2007-2011 (Fig. 6). At the beginning of this period large fluctuations in function $\gamma(h)$ values occur. Similarly as in the semivariogram of $\mathrm{Fe}$ content, also in the variogram of $\mathrm{NH}_{4}{ }^{+}$content one can notice a substantial share of nugget effect $C_{0}$ in overall variation $C$.

The analysis of the directional semivariograms (D-90) carried out for two basic quality parameters of underground water in the Klodzko water intake area showed a slow upward trend in Fe content which became apparent only over a long time period, i.e. over the years 1977-2012 [1,4]. In comparison with the

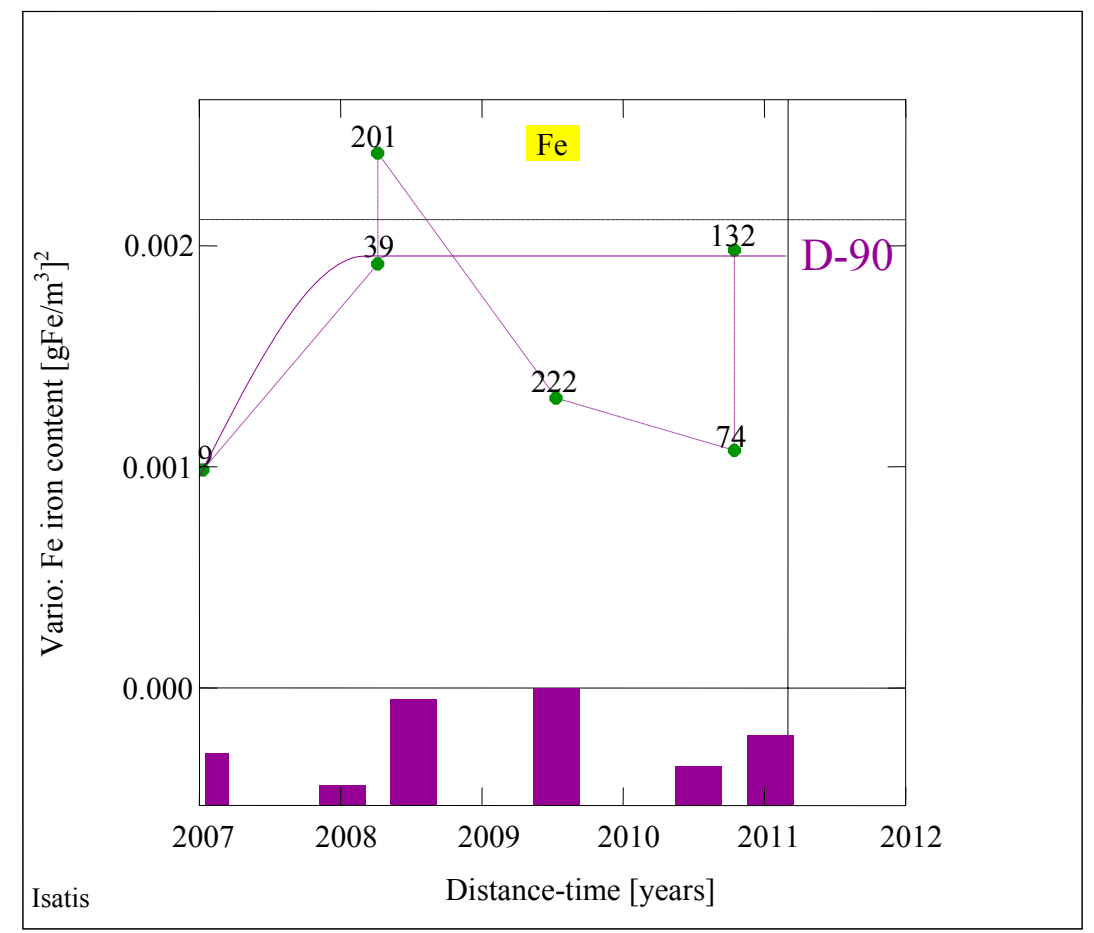

Fig. 4 Directional semivariogram (D-90) of Fe iron content $\left[\mathrm{gFe} / \mathrm{m}^{3}\right]^{2}$ in Klodzko town area water supply system. 


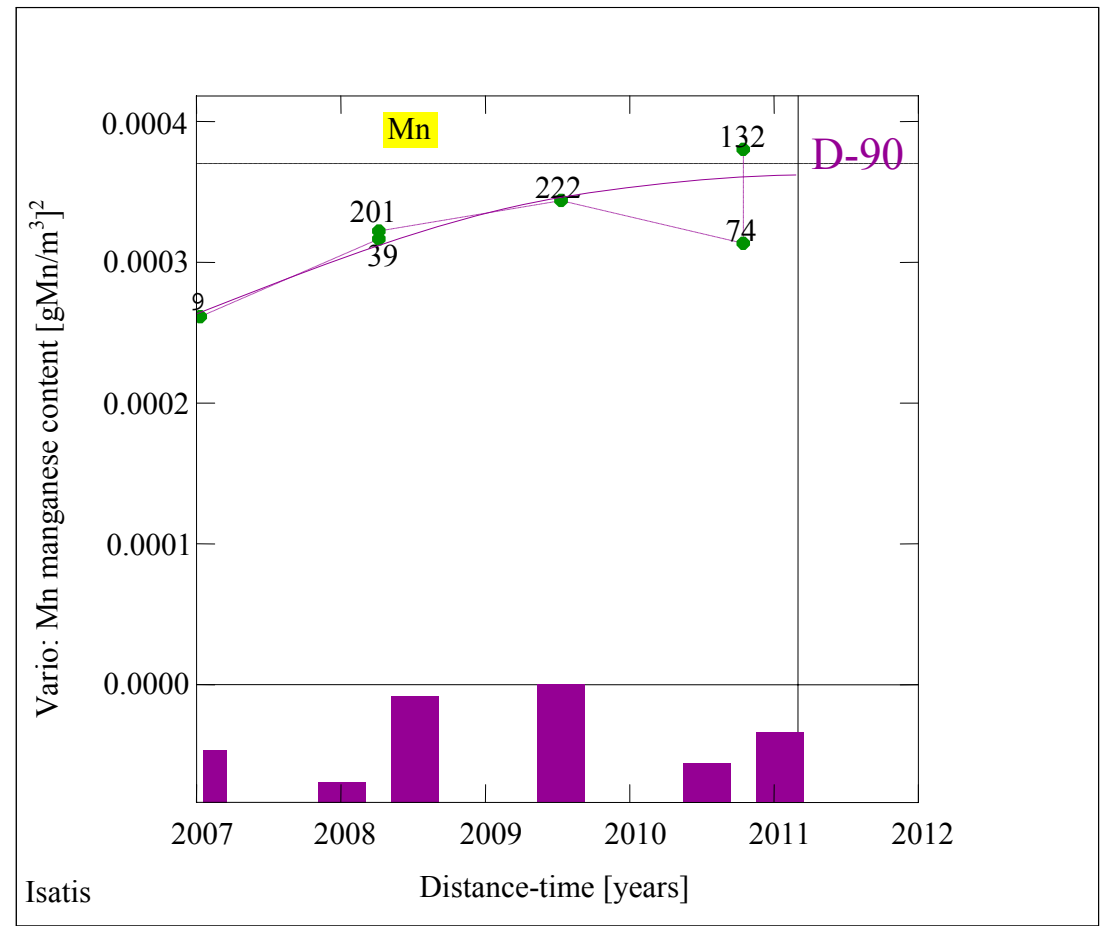

Fig. 5 Directional semivariogram (D-90) of Mn manganese content $\left[\mathrm{gMn} / \mathrm{m}^{3}\right]^{2}$ in Klodzko town area water supply system.

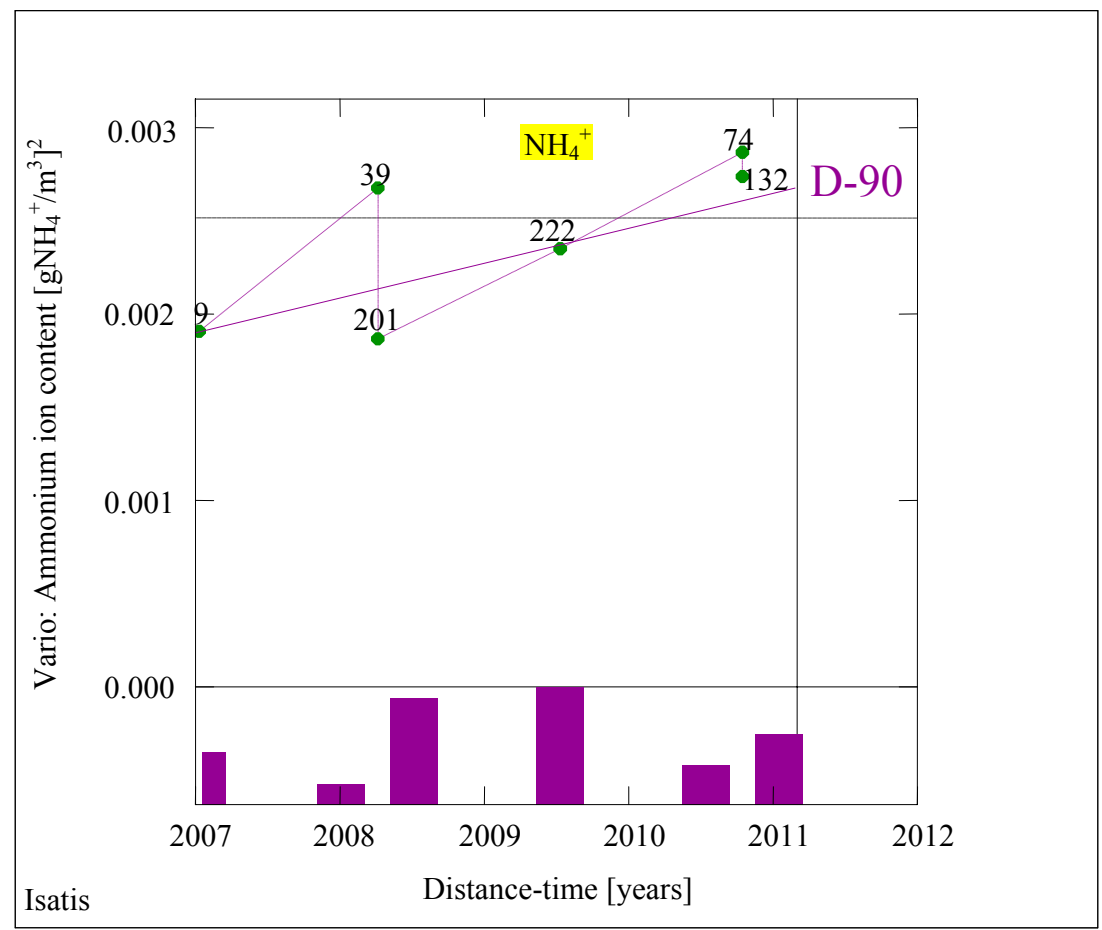

Fig. 6 Directional semivariogram (D-90) of $\mathrm{NH}_{4}^{+}$content $\left[\mathrm{gNH}_{4}{ }^{+} / \mathrm{m}^{3}\right]^{2}$ in Klodzko town area water supply system.

semivariogram (D-90) of Mn content in the network water (Fig. 5), the semivariogram of Mn content rised sharply in the initial part of the function $\gamma(h)$ graph and stabilized only later $[1,4]$. In the former case, the increase in the values of $\gamma(h)(\mathrm{Mn})$ was consistent, but proceeded slower and the changes in the value of $\gamma(h)$ were more moderate.

The directional semivariogram of Fe content in the 
network water was characterized by the shortest range of influence $a$ of 1 year (Table 5). The directional semivariogram of Mn content showed a longer range $a$ of 1.5-3.5 years. The longest range $a$, amounting to 6 years, characterized the directional semivariogram of ion $\left(\mathrm{NH}_{4}^{+}\right)$content. In the studied time interval of 2007-2011 Fe content in the network showed a much lower correlation than that of $\mathrm{Mn}$ content or $\mathrm{NH}_{4}^{+}$ content. In the case of the latter parameter, the correlation could be traced over a longer period of time.

The directional semivariograms of the basic water quality parameters in the water supply network were approximated using a combination of two spherical models and the nugget effect (Table 5). The results of the cross-validation of the adopted theoretical models of the directional semivariograms (D-90), performed using ordinary point kriging, show that the latter was approximated correctly.

The obtained coefficients $(r)$ of the correlation between original values $Z$ and estimated averages $Z^{*}$ were in a range of 0.61 (Fe content), 0.19 (Mn content) and $0.578\left(\mathrm{NH}_{4}^{+}\right.$content $)$.

The standardized errors, calculated using the test data reached: 1.00 (Fe content and $\mathrm{Mn}$ content) and $0.79\left(\mathrm{NH}_{4}{ }^{+}\right.$content $)$while the ones calculated using the robust data amounted to: 0.31 (Fe content and $\mathrm{Mn}$ content) and $0.19\left(\mathrm{NH}_{4}^{+}\right.$content).

For comparison, the ranges of influence $a$ of the directional semivariograms (D-90) determined on the basis of the underground water sampling data for the longer period of 1977-2012 amounted to about 3 years for Fe content and to 2 years for Mn content $[1,4]$. The correlation of the Fe content in the underground water extended over a longer time period than that of the Mn content.

\subsection{Analysis of Directional Semivariograms of Treated Water Quality Parameters (Years 2008-2011)}

Analyzing the tendencies in the variation of the network water quality parameters determined from the directional semivariograms (D-90) and comparing them with the results of the structural analysis for the treated water one finds both a certain similarity and dissimilarities in the graphs of function $\gamma(h)$. One should mention here the small size of the data sample $(n=16)$ available for the calculation of the directional semivariograms (D-90) of the treated water quality parameters (Table 1) in comparison with the size of the network water data sample $(\mathrm{n}=66)$ (Table 2$)$.

In the years 2008-2012 the directional semivariogram (D-90) of Fe content in the treated water shows some periodic variation in the value of $\gamma(h)$, with nugget effect $C_{0}$ manifesting itself (Fig. 7). A certain analogy to the semivariogram (D-90) of $\mathrm{Fe}$ content in the network water is observed here (Fig. 4).

The directional semivariogram (D-90) of Mn content in the treated water, with a distinct small share of the random component (nugget effect $C_{0}$ ), shows a clear increase in the value of function $\gamma(h)$ towards the years 2009-2010 (Fig. 8). In the further part of the graph a decrease in the value of $\gamma(h)$ is observed.

In the considered time period (the years 2008-2011) a very strong growing trend in the $\gamma(h)$ value of the directional semivariogram of $\mathrm{NH}_{4}^{+}$content in the treated water is observed over the years (Fig. 9). This trend is visible in the entire course of the graph.

Table 5 Comparison of geostatistical model values of directional semivariograms (D-90) for water quality parameters in water supply system (years 2007-2011).

\begin{tabular}{|c|c|c|c|c|c|}
\hline Analyzed parameter & $\begin{array}{l}\text { Nugget } \\
C_{0} \\
\left(\mathrm{~g} / \mathrm{m}^{3}\right)^{2} \\
\end{array}$ & $\begin{array}{l}\text { Partial variance } \\
C^{\prime} \\
\left(\mathrm{g} / \mathrm{m}^{3}\right)^{2}\end{array}$ & $\begin{array}{l}\text { Total sill variance } \\
C \\
\left(\mathrm{~g} / \mathrm{m}^{3}\right)^{2}\end{array}$ & $\begin{array}{l}\text { Range of influence } \\
a \text { (years) }\end{array}$ & $\begin{array}{l}\text { Basic model } \\
\text { structures }\end{array}$ \\
\hline Content of Fe iron $\left(\mathrm{gFe} / \mathrm{m}^{3}\right)$ & 0.0009 & 0.0010 & 0.0019 & 0.93 & $\begin{array}{l}\text { Nugget effect, } \\
\text { spherical, }\end{array}$ \\
\hline $\begin{array}{l}\text { Content of Mn manganese } \\
\left(\mathrm{gMn} / \mathrm{m}^{3}\right)\end{array}$ & 0.0003 & $\begin{array}{l}2.7636 \\
7.1258\end{array}$ & 9.8897 & $\begin{array}{l}2.08 \\
3.43\end{array}$ & $\begin{array}{l}\text { Nugget effect, } \\
\text { spherical, spherical }\end{array}$ \\
\hline $\begin{array}{l}\text { Content of } \mathrm{NH}_{4}^{+} \text {mmonium } \\
\text { ion }\left(\mathrm{gNH}_{4}^{+} / \mathrm{m}^{3}\right)\end{array}$ & 0.0019 & 0.0013 & 0.0034 & $\begin{array}{l}5.00 \\
5.89\end{array}$ & $\begin{array}{l}\text { Nugget effect, } \\
\text { linear }\end{array}$ \\
\hline
\end{tabular}




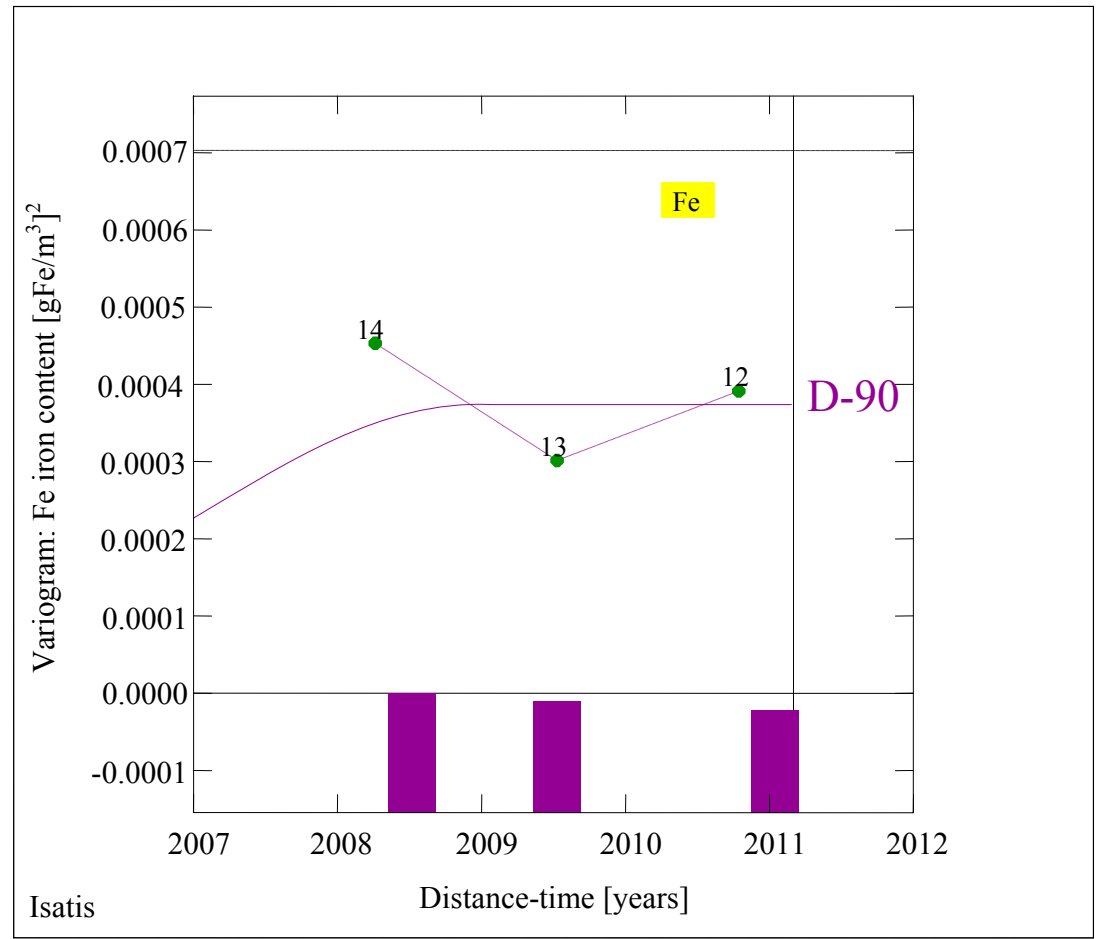

Fig. 7 Directional semivariogram (D-90) of $\mathrm{Fe}$ iron content $\left[\mathrm{gFe} / \mathrm{m}^{3}\right]^{2}$ in treated water in Klodzko town area.

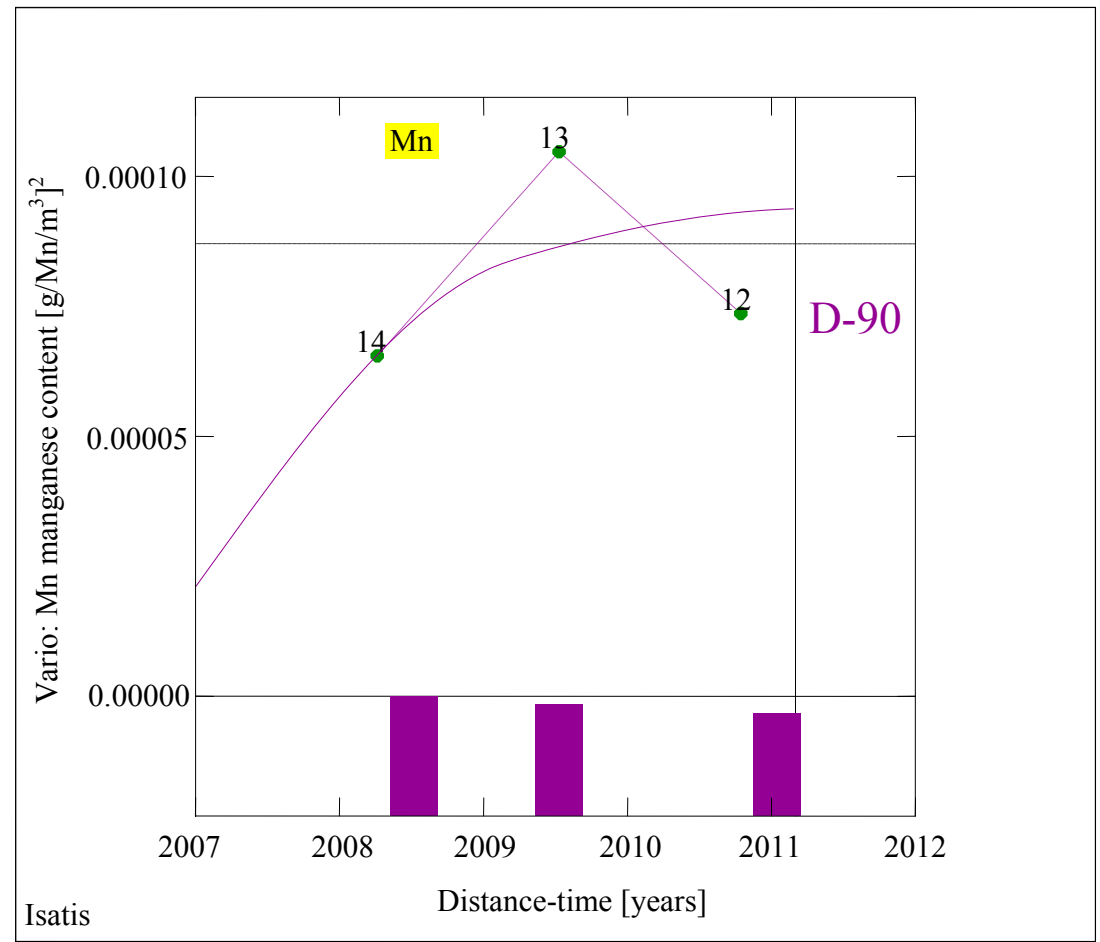

Fig. 8 Directional semivariogram (D-90) of Mn manganese content $\left[\mathrm{gMn} / \mathrm{m}^{3}\right]^{2}$ in treated water in Klodzko town area.

The directional variograms (D-90) were approximated with a single spherical model with the nugget effect or with a combination of two such models, with the nugget effect (Table 6). The longest range $a$ of correlation characterized the semivariogram (D-90) of $\mathrm{NH}_{4}^{+}$ content in the treated water ( $a=$ about 4 years) (Fig. 8), the intermediate correlation range $a$ characterized the semivariogram of Mn content ( $a=$ about 2 years) and a 
shorter correlation range $a$ characterized the semivariogram of Fe content ( $a=1.55$ year) (Fig. 7) (Table 6). A certain similarity to the shorter range $a$ of the semivariogram (D-90) of Fe content in the network water is visible here (Table 5).

The results of the cross-validation of the applied models of the treated water quality parameter semivariograms indicate relatively low values of the coefficients of the correlation between original values $Z$ and estimated averages $Z^{*}$. The correlation coefficients amounted to respectively: $r=-0.23$ (Fe content), $r=-0.182$ (Mn content) and $r=0.375\left(\mathrm{NH}_{4}{ }^{+}\right.$ content).

The standardized errors would reach the standard value of 1 when the test data were used in the calculations and would amount to respectively 0.46 (Fe content), 0.48 (Mn content) and $0.33\left(\mathrm{NH}_{4}{ }^{+}\right.$content) when the robust data were used.

When the shorter interval of 2007-2011 is analyzed, as it was done for the network water and the treated water, then certain periodicity in the changes in the $\gamma(h)$ value of the $\mathrm{Fe}$ content becomes apparent. As regards the Mn content, a similar tendency as for the content of this element in the underground water is visible, but the increase in the $\gamma(h)$ value is slower and the variation is more moderate. A tendency towards periodic changes in the value of the Fe content semivariogram function and a clear trend in the variation of the other two parameters - the $\mathrm{Mn}$ content and the $\mathrm{NH}_{4}{ }^{+}$-are observed in the analyzed period.

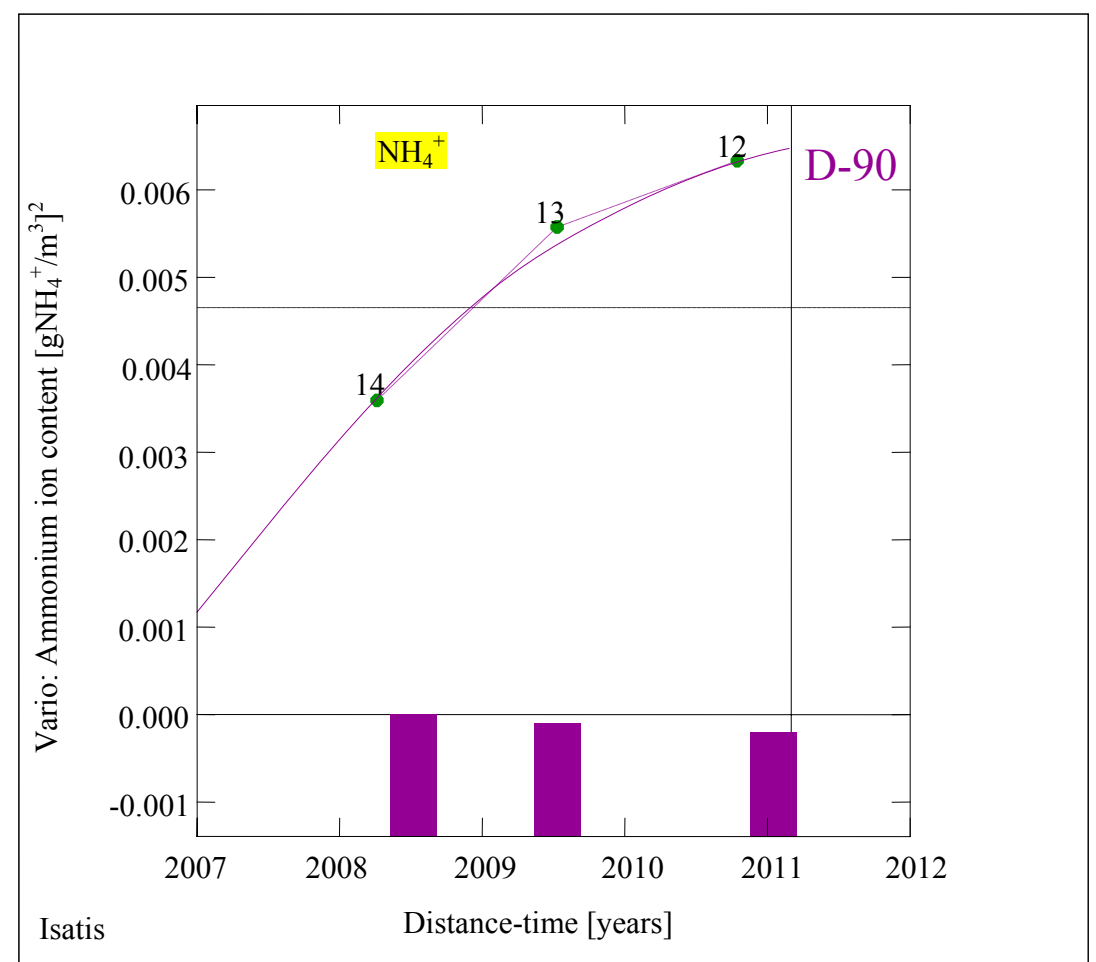

Fig. 9 Directional semivariogram (D-90) of $\mathrm{NH}_{4}{ }^{+}$content $\left[\mathrm{gNH}_{4}{ }^{+} / \mathrm{m}^{3}\right]^{2}$ in treated water in Klodzko town area.

Table 6 Comparison of geostatistical model values of directional semivariograms (D-90) for treated water quality parameters (years 2008-2011).

\begin{tabular}{llllll}
\hline $\begin{array}{l}\text { Analyzed } \\
\text { parameter }\end{array}$ & $\begin{array}{l}\text { Nugget effect variance } \\
C_{0} \\
\left(\mathrm{~g} / \mathrm{m}^{3}\right)^{2}\end{array}$ & $\begin{array}{l}\text { Partial variance } \\
C^{\prime} \\
\left(\mathrm{g} / \mathrm{m}^{3}\right)^{2}\end{array}$ & $\begin{array}{l}\text { Total sill variance } \\
C \\
\left(\mathrm{~g} / \mathrm{m}^{3}\right)^{2}\end{array}$ & $\begin{array}{l}\text { Range of } \\
\text { influence } \\
a \text { (years) }\end{array}$ & $\begin{array}{l}\text { Basic model } \\
\text { structures }\end{array}$ \\
\hline $\begin{array}{l}\text { Content of } \mathrm{Fe} \text { iron }\left(\mathrm{gFe} / \mathrm{m}^{3}\right) \\
\begin{array}{l}\text { Content of Mn manganese } \\
\left(\mathrm{gMn} / \mathrm{m}^{3}\right)\end{array}\end{array}$ & 0.0002 & 0.0001 & 0.0003 & 1.55 & Nugget effect, spherical, \\
$\begin{array}{l}\text { Content } \text { of NH}_{4}{ }^{+} \text {ammonium } \\
\text { ion }\left(\mathrm{gNH}_{4}{ }^{+} / \mathrm{m}^{3}\right)\end{array}$ & - & 9.2881 & 1.94 & Nugget effect, spherical, \\
\hline
\end{tabular}


Generally, the observed trends in the variation of the $\mathrm{Fe}$ and $\mathrm{Mn}$ content in the treated water and in the water in the Kłodzko water pipe network reflect the previously determined tendencies in the variation in the concentration of the elements in the underground water in the Kłodzko water intake area. In the longer time interval of 1977-2012, the trends are even more distinct. In the case of the Fe content, a slow upward trend in the value of semivariogram function $\gamma(h)$ is observed, whereas the Mn content behaves differently. In the longer period of 1977-2012, initially the changes in the Mn content in the variogram are sharp and then they stabilize as the value of $\gamma(h)$ slowly increases over time.

\section{Results of Estimation}

The results of the estimation of averages $Z^{*}$ and estimation standard deviation $\sigma_{k}$ of the water quality parameters calculated in 253,825 nodes of the elementary grid covering the Klodzko town area water supply network are presented in Tables 7 and 8 .

The variation coefficients $(V)$ of averages $Z^{*}$ indicate merely moderate variation in Fe content and $\mathrm{Mn}$ content and high variation in ammonium ion $\left(\mathrm{NH}_{4}{ }^{+}\right)$ content (Table 7). In the case of the latter parameter, the result of the calculations of coefficient $V$ indicates considerable variation in $\mathrm{NH}_{4}{ }^{+}$content over the years 2007-2011, which can explain some difficulties in matching a suitable model to the directional semivariogram.

The coefficients of the correlation between averages $Z^{*}$ of the network water quality parameters show an insignificant or weak (negative or positive) correlation, which is due to the lack of correlation between the original values $Z$ of the parameters:

$\mathrm{Fe} / \mathrm{Mn}-0.18, \mathrm{Fe} / \mathrm{NH}_{4}{ }^{+}-0.24, \mathrm{NH}_{4}{ }^{+} \mathrm{Mn}-0.36$.

The coefficients of variation $V$ of estimation standard deviation $\sigma_{k}$ (Table 8) indicate small variation of this parameter for $\mathrm{Fe}$ content and $\mathrm{NH}_{4}{ }^{+}$content and very small variation for Mn content.

Thus the results of the calculations of estimation deviation $\sigma_{k}$ (Table 8) validate the estimation of the $Z^{*}$ values of the network water quality parameters.

Only the histograms showing the distribution of $\mathrm{Fe}$ content averages $Z^{*}$ and estimation deviations $\sigma_{k}$ of $\mathrm{NH}_{4}{ }^{+}$content are clearly positively skew, and sharp (Table 9).

The averages $Z^{*}$ and estimation standard deviations $\sigma_{k}$ of the treated water quality parameters in 71,500 nodes of the elementary grid covering the Klodzko town water supply network were estimated using the data for the years 2008-2011 (Tables 10 and 11).

The variation coefficients $(V)$ for the averages $Z^{*}$ of the treated water quality parameters confirm the high variation in $\mathrm{Mn}$ content and the even higher variation in $\mathrm{NH}_{4}{ }^{+}$content (Table 10). The variation coefficients $(V)$ for estimation standard deviations $\sigma_{k}$ indicate high variation in $\mathrm{Mn}$ content and moderate variation in $\mathrm{NH}_{4}^{+}$ content (Table 11). This can be due to the small size of the data sample $(n=16)$ used to model and estimate averages $Z^{*}$. The same applies to the size of the date sample $(n=16)$ used to estimate the averages $Z^{*}$ of $\mathrm{Fe}$ content, but the variations in averages $Z^{*}$ and in $\sigma_{k}$ values are small (Tables 10 and 11).

The coefficient of correlation between the averages $Z^{*}$ of the treated water quality parameters indicates a weak (negative) correlation for $\mathrm{Mn}$ content and $\mathrm{NH}_{4}{ }^{+}$

Table 7 Global statistics of estimated averages $Z^{*}$ of water quality parameters in water supply system (results of ordinary block kriging for years 2007-2011).

\begin{tabular}{|c|c|c|c|c|c|c|}
\hline Analyzed parameter & $\begin{array}{l}\text { Number of grid } \\
\text { nodes } n\end{array}$ & $\begin{array}{l}\text { Min. value } \\
X_{\min } \\
\left(\mathrm{g} / \mathrm{m}^{3}\right)\end{array}$ & $\begin{array}{l}\text { Max. value } \\
X_{\max } \\
\left(\mathrm{g} / \mathrm{m}^{3}\right)\end{array}$ & $\begin{array}{l}\text { Average value } \\
X \\
\left(\mathrm{~g} / \mathrm{m}^{3}\right)\end{array}$ & $\begin{array}{l}\text { St. deviation } \\
S \\
\left(\mathrm{~g} / \mathrm{m}^{3}\right)\end{array}$ & $\begin{array}{l}\text { Variation coefficient } \\
V \\
(\%)\end{array}$ \\
\hline Content of Fe iron & 253,825 & 0.0392 & 0.1682 & 0.0649 & 0.0191 & 29.36 \\
\hline Content of Mn manganese & 253,825 & 0.0143 & 0.0419 & 0.0205 & 0.0063 & 30.51 \\
\hline $\begin{array}{l}\text { Content of } \mathrm{NH}_{4}{ }^{+} \text {ammonium } \\
\text { Ion }\end{array}$ & 253,825 & 0.0153 & 0.1017 & 0.0456 & 0.0284 & 62.40 \\
\hline
\end{tabular}


Table 8 Global statistics of estimation standard deviation $\sigma_{\mathrm{k}}$ for water quality parameters in water supply system (results of ordinary block kriging for years 2007-2011).

\begin{tabular}{|c|c|c|c|c|c|c|}
\hline $\begin{array}{l}\text { Chemical } \\
\text { parameter }\end{array}$ & $\begin{array}{l}\text { Number } \\
\text { of grid nodes } \\
n\end{array}$ & $\begin{array}{l}\text { Min value } \\
X_{\min } \\
\left(\mathrm{g} / \mathrm{m}^{3}\right)\end{array}$ & $\begin{array}{l}\text { Max value } \\
X_{\max } \\
\left(\mathrm{g} / \mathrm{m}^{3}\right)\end{array}$ & $\begin{array}{l}\text { Average value } \\
X \\
\left(\mathrm{~g} / \mathrm{m}^{3}\right)\end{array}$ & $\begin{array}{l}\text { St. deviation } \\
S \\
\left(\mathrm{~g} / \mathrm{m}^{3}\right)\end{array}$ & $\begin{array}{l}\text { Variation coefficient } \\
V \\
(\%)\end{array}$ \\
\hline Content of $\mathrm{Fe}$ iron & 253,825 & 0.0135 & 0.0307 & 0.0233 & 0.0049 & 21.22 \\
\hline $\begin{array}{l}\text { Content of } \mathrm{Mn} \\
\text { manganese }\end{array}$ & 253,825 & 0.0055 & 0.0101 & 0.0067 & 0.0009 & 13.43 \\
\hline $\begin{array}{l}\text { Content of } \mathrm{NH}_{4}^{+} \\
\text {ammonium ion }\end{array}$ & 253,825 & 0.0135 & 0.0322 & 0.0166 & 0.0035 & 21.07 \\
\hline
\end{tabular}

Table 9 Comparison of skewness $g_{1}$ and kurtosis $g_{2}$ for histograms of distribution of water quality parameters (estimated averages $Z^{*}$ and $\sigma_{k}$ ) in water supply system.

\begin{tabular}{lcc}
\hline Analyzed parameter & Skewness $g_{1}$ & Kurtosis $g_{2}$ \\
\hline \multirow{2}{*}{ Content of $\mathrm{Fe}$ iron $\left(\mathrm{gFe} / \mathrm{m}^{3}\right)$} & 3.41 & 16.15 \\
& -0.74 & 2.40 \\
Content of $\mathrm{Mn}$ manganese $\left(\mathrm{gMn} / \mathrm{m}^{3}\right)$ & 1.69 & 5.41 \\
& 2.11 & 7.93 \\
Content of $\mathrm{NH}_{4}{ }^{+}$ammonium ion $\left(\mathrm{gNH}_{4}^{+} / \mathrm{m}^{3}\right)$ & 0.48 & 1.92 \\
\end{tabular}

Table 10 Global statistics of estimated averages $Z^{*}$ of treated water quality parameters(results of ordinary block kriging for years 2008-2011).

\begin{tabular}{|c|c|c|c|c|c|c|}
\hline Analyzed parameter & $\begin{array}{l}\text { Number } \\
\text { of grid nodes } \\
n\end{array}$ & $\begin{array}{l}\text { Min. value } \\
X_{\min } \\
\left(\mathrm{g} / \mathrm{m}^{3}\right)\end{array}$ & $\begin{array}{l}\text { Max. value } \\
X_{\max } \\
\left(\mathrm{g} / \mathrm{m}^{3}\right)\end{array}$ & $\begin{array}{l}\text { Average value } \\
X \\
\left(\mathrm{~g} / \mathrm{m}^{3}\right)\end{array}$ & $\begin{array}{l}\text { St. deviation } \\
S \\
\left(\mathrm{~g} / \mathrm{m}^{3}\right)\end{array}$ & $\begin{array}{l}\text { Variation coefficient } \\
V \\
(\%)\end{array}$ \\
\hline Content of Fe iron & 71,500 & 0.0399 & 0.0795 & 0.0564 & 0.0080 & 14.18 \\
\hline Content of Mn manganese & 71,500 & 0.0035 & 0.0372 & 0.0141 & 0.0069 & 49.15 \\
\hline $\begin{array}{l}\text { Content of } \mathrm{NH}_{4}^{+} \text {monium } \\
\text { ion }\end{array}$ & 71,500 & 0.0183 & 0.2064 & 0.0678 & 0.0441 & 65.07 \\
\hline
\end{tabular}

Table 11 Global statistics of estimation standard deviation $\sigma_{k}$ for treated water quality parameters (results of ordinary block kriging for years 2008-2011).

\begin{tabular}{|c|c|c|c|c|c|c|}
\hline Analyzed parameter & $\begin{array}{l}\text { Number of grid } \\
\text { nodes } n\end{array}$ & $\begin{array}{l}\text { Min. value } \\
X_{\min } \\
\left(\mathrm{g} / \mathrm{m}^{3}\right)\end{array}$ & $\begin{array}{l}\text { Max. value } \\
X_{\max } \\
\left(\mathrm{g} / \mathrm{m}^{3}\right)\end{array}$ & $\begin{array}{l}\text { Average value } \\
X \\
\left(\mathrm{~g} / \mathrm{m}^{3}\right)\end{array}$ & $\begin{array}{l}\text { St. deviation } \\
S \\
\left(\mathrm{~g} / \mathrm{m}^{3}\right)\end{array}$ & $\begin{array}{l}\text { Variation coefficient } \\
V \\
(\%)\end{array}$ \\
\hline Content of Fe iron & 71,500 & 0.0119 & 0.0155 & 0.0126 & 0.0013 & 10.56 \\
\hline Content of Mn manganese & 71,500 & 0.0031 & 0.0099 & 0.0044 & 0.0024 & 55.76 \\
\hline Content of $\mathrm{NH}_{4}{ }^{+}$mmonium ion & 71,500 & 0.0277 & 0.0702 & 0.0347 & 0.0134 & 38.57 \\
\hline
\end{tabular}

content, i.e. $r$ value amounting to:

$$
\mathrm{Mn} / \mathrm{NH}_{4}{ }^{+}-0.296 \text {. }
$$

\section{Spatial visualization of Estimation Results}

Raster maps (in perspective view) showing the distribution of the averages $Z^{*}$ of the network water quality parameters (Fe content-Figs. 10-12, Mn content-Figs. 13-15, $\mathrm{NH}_{4}{ }^{+}$content-Figs. 16-18) for selected years are presented below. Thanks to the maps one can see to what degree the images of the distribution of averages $Z^{*}$ for the particular parameters change over the years.

\subsection{Iron (Fe) Content}

In 2007 the largest area with the lowest averages $Z^{*}$ of Fe content ( $Z^{*}: 0.06133-0.06135 \mathrm{gFe} / \mathrm{m}^{3}$ ) became apparent (Fig. 10). At the same time the maximum averages $Z^{*}$ of $\mathrm{Fe}$ content ranged from 0.06138 to $0.06140 \mathrm{gFe} / \mathrm{m}^{3}$.

In 2010 in the S and SE part of the area a band of the maximum averages $Z^{*}$ of $\mathrm{Fe}$ content, ranging from 0.066060 to $0.066070 \mathrm{~g} \mathrm{Fe} / \mathrm{m}^{3}$, extended (Fig. 11). The 


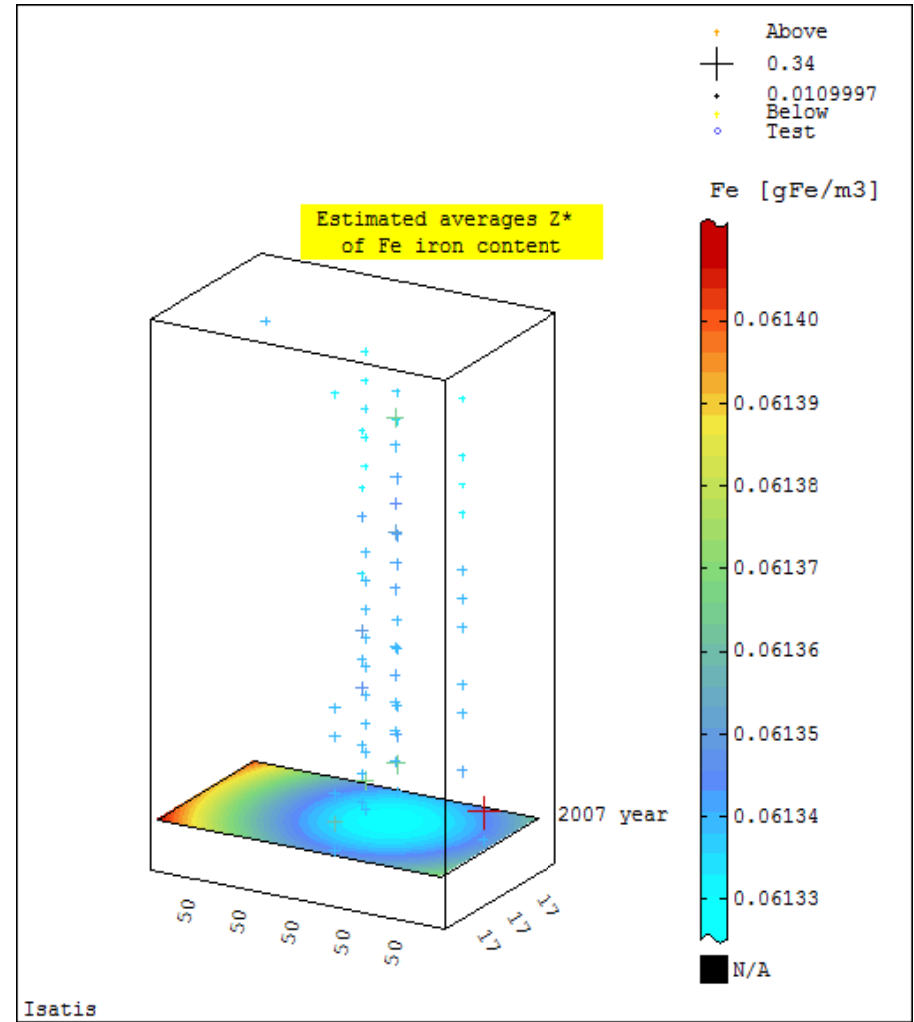

Fig. 10 Raster map (in perspective view) showing distribution of estimated $\mathrm{Fe}$ iron content $\left[\mathrm{gFe} / \mathrm{m}^{3}\right]$ averages $Z^{*}$ in $\mathrm{Klodzko}$ town area water supply system in 2007.

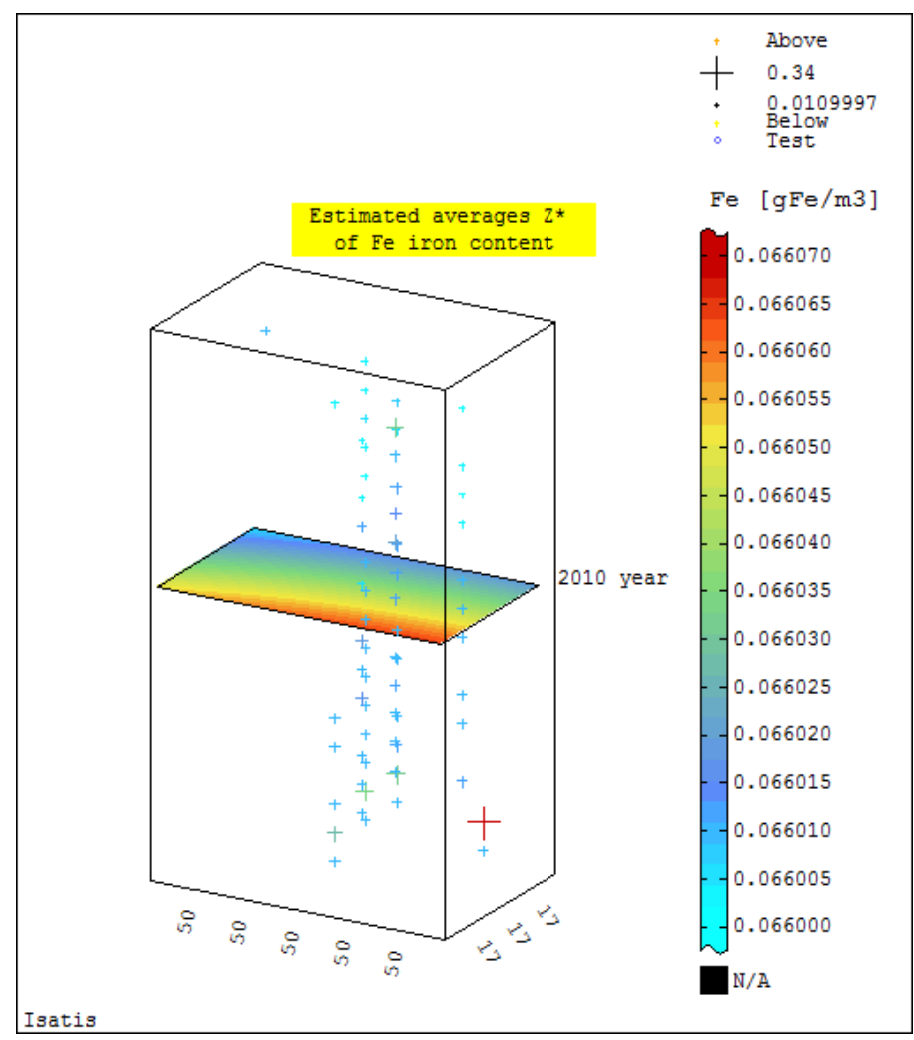

Fig. 11 Raster map (in perspective view) showing distribution of estimated Fe iron content $\left[\mathrm{gFe} / \mathrm{m}^{3}\right]$ averages $Z^{*}$ in $\mathrm{Klodzko}$ town area water supply system in $\mathbf{2 0 1 0 .}$ 
lowest averages $Z *$ ranged from 0.066000 to 0.066015 $\mathrm{g} \mathrm{Fe} / \mathrm{m}^{3}$ (the $N$ part of the area).

In 2011 the maximum averages $Z^{*}$ of $\mathrm{Fe}$ content decreased (in comparison with 2010) to the range of 0.06760-0.06770 g Fe $/ \mathrm{m}^{3}$ while the lowest averages $Z^{*}$ ranged from 0.06695 to $0.06710 \mathrm{~g} \mathrm{Fe} / \mathrm{m}^{3}$ (Fig. 12). The maximum averages $Z^{*}$ of $\mathrm{Fe}$ content were found in the $\mathrm{S}$ and SW part of the area while the minimum averages $Z^{*}$ of Fe content occurred in the NE part.

\subsection{Manganese (Mn) Content}

On the raster maps showing the distribution of $\mathrm{Mn}$ content averages $Z^{*}$ calculated for the particular years: 2007, 2010 and 2011 (Figs. 13-15) one can see that the maximum averages $Z^{*}$ covered considerable areas of the water supply network. They occurred mostly in the west (W) and south-west (SW) parts, but also in the central part of the town of Klodzko.

On the map for 2007 the highest averages $Z^{*}$ of Mn content in water in the water supply network ranged from 0.01986 to $0.01990 \mathrm{gMn} / \mathrm{m}^{3}$, while the lowest averages $Z^{*}$ ranged from 0.01974 to $0.01978 \mathrm{gMn} / \mathrm{m}^{3}$ (Fig. 13).

On the map for 2010 two ranges stood out, i.e. the range of maximum averages $Z^{*}$ : 0.0215037-0.0215047 $\mathrm{g} \mathrm{Mn} / \mathrm{m}^{3}$ and the range of the lowest averages $Z^{*}$ : $0.0214977-0.0214992 \mathrm{gMn} / \mathrm{m}^{3}$ (Fig. 14).

On the map for 2011 the Mn concentration in the network water was found to vary. An extensive subarea of Mn content averages $Z^{*}$, representing the highest averages $Z^{*}$ ranging from 0.04188 to $0.04192 \mathrm{~g} \mathrm{Mn} / \mathrm{m}^{3}$, occurred in the SW part of the area (Fig. 15). The lowest Mn content averages $Z^{*}$ ranged from 0.04164 to $0.04170 \mathrm{gMn} / \mathrm{m}^{3}$.

\subsection{Ammonium Ion $\left(\mathrm{NH}_{4}^{+}\right)$Content}

Exemplary raster maps of estimated averages $Z^{*}$ of $\mathrm{NH}_{4}{ }^{+}$ion content in the network water showed that this parameter tended to increase from 2007 to 2010 (Figs. 16 and 17).

In the map for 2007 the maximum averages $Z^{*}$ ranged from 0.051436 to $0.051440 \mathrm{gNH}_{4}^{+} / \mathrm{m}^{3}$ (Fig. 16).

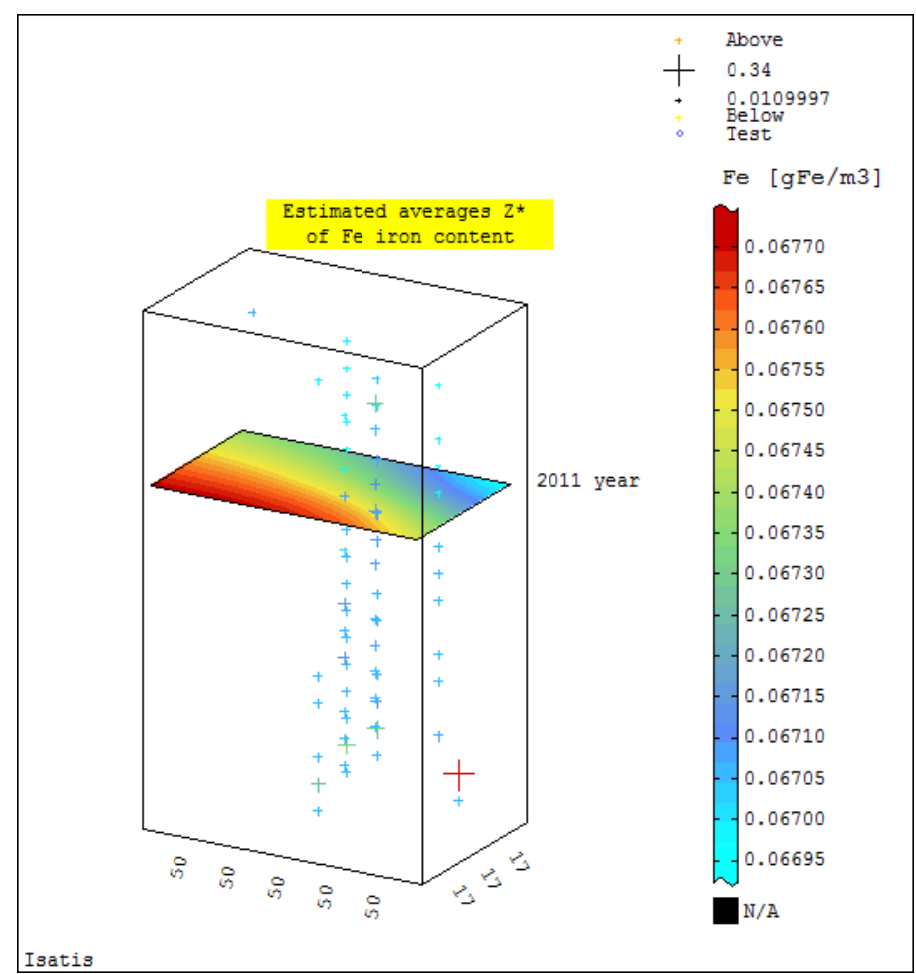

Fig. 12 Raster map (in perspective view) showing distribution of estimated $\mathrm{Fe}$ iron content $\left[\mathrm{gFe} / \mathrm{m}^{3}\right]$ averages $Z^{*}$ in $\mathrm{Klodzko}$ town area water supply system in 2011. 

Parameters in Klodzko Water Supply System (SW Part of Poland)

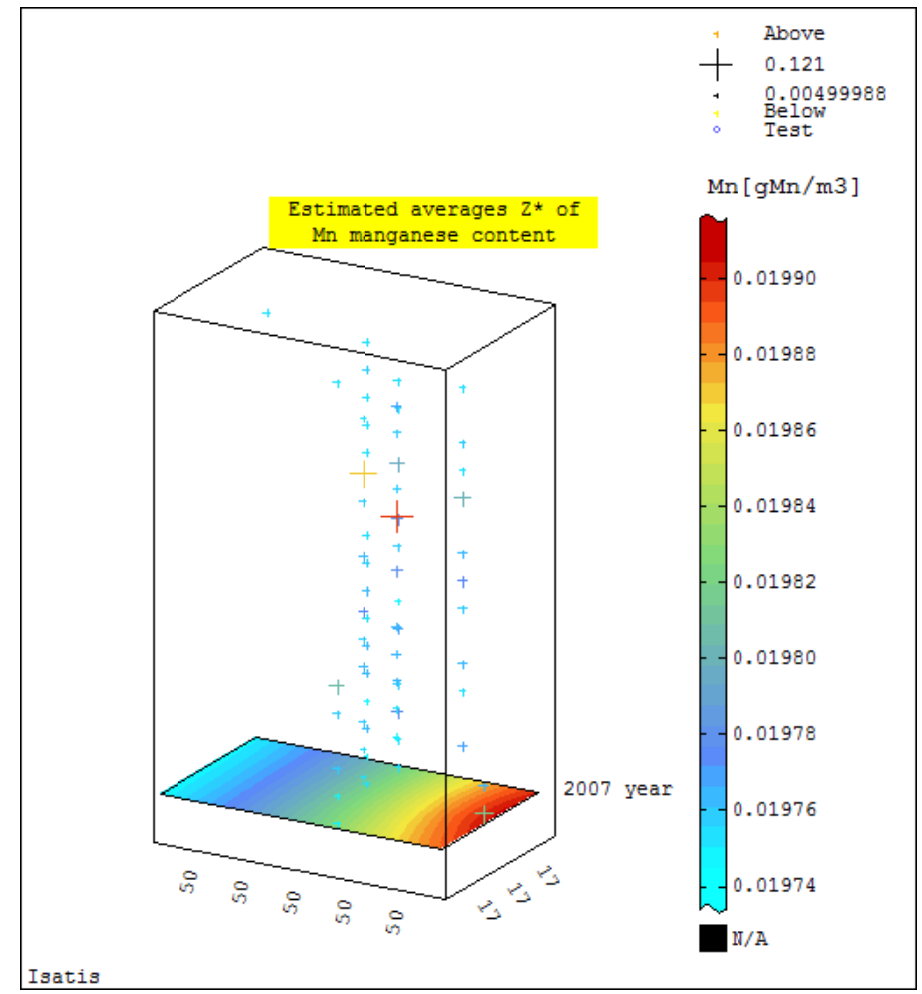

Fig. 13 Raster map (in perspective view) showing distribution of estimated averages $Z^{*}$ of Mn content $\left[\mathrm{g} / \mathrm{m}^{3}\right]$ in $\mathrm{Klodzko}$ town water supply system in 2007.

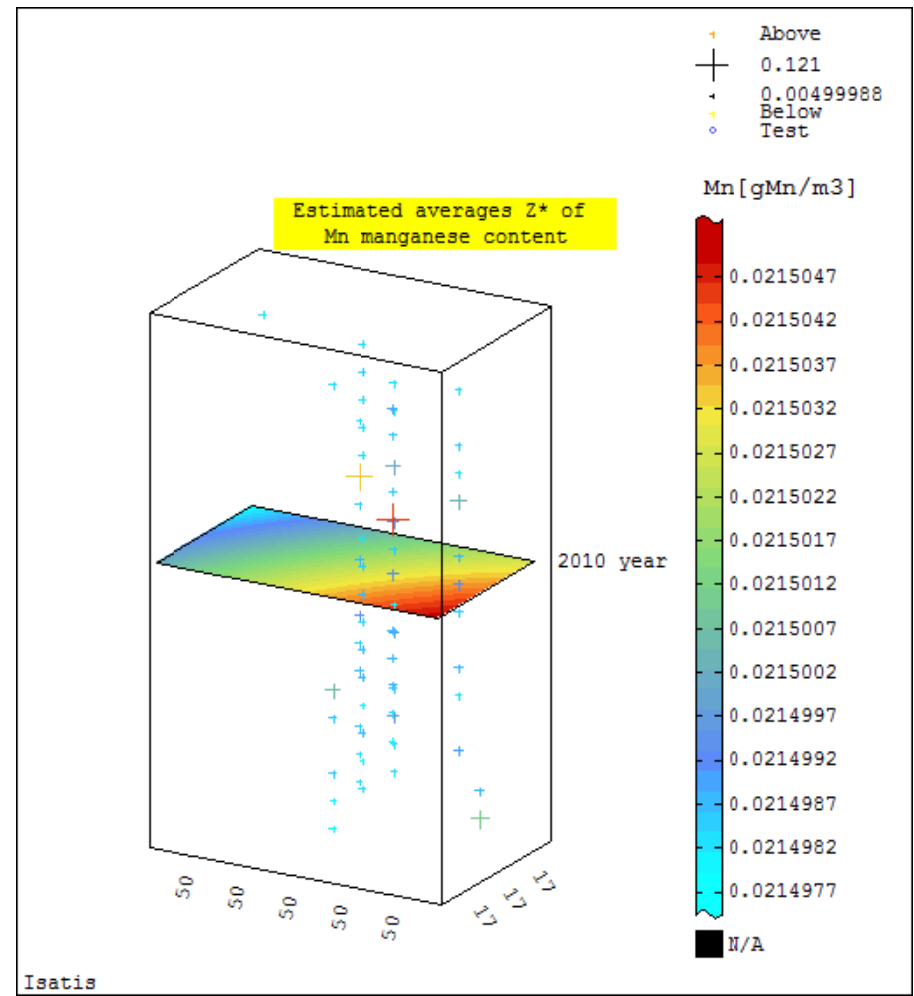

Fig. 14 Raster map (in perspective view) showing distribution of estimated averages $Z^{*}$ of Mn content $\left[\mathrm{gMn} / \mathrm{m}^{3}\right]$ in $\mathrm{Klodzko}$ town water supply system in 2010. 


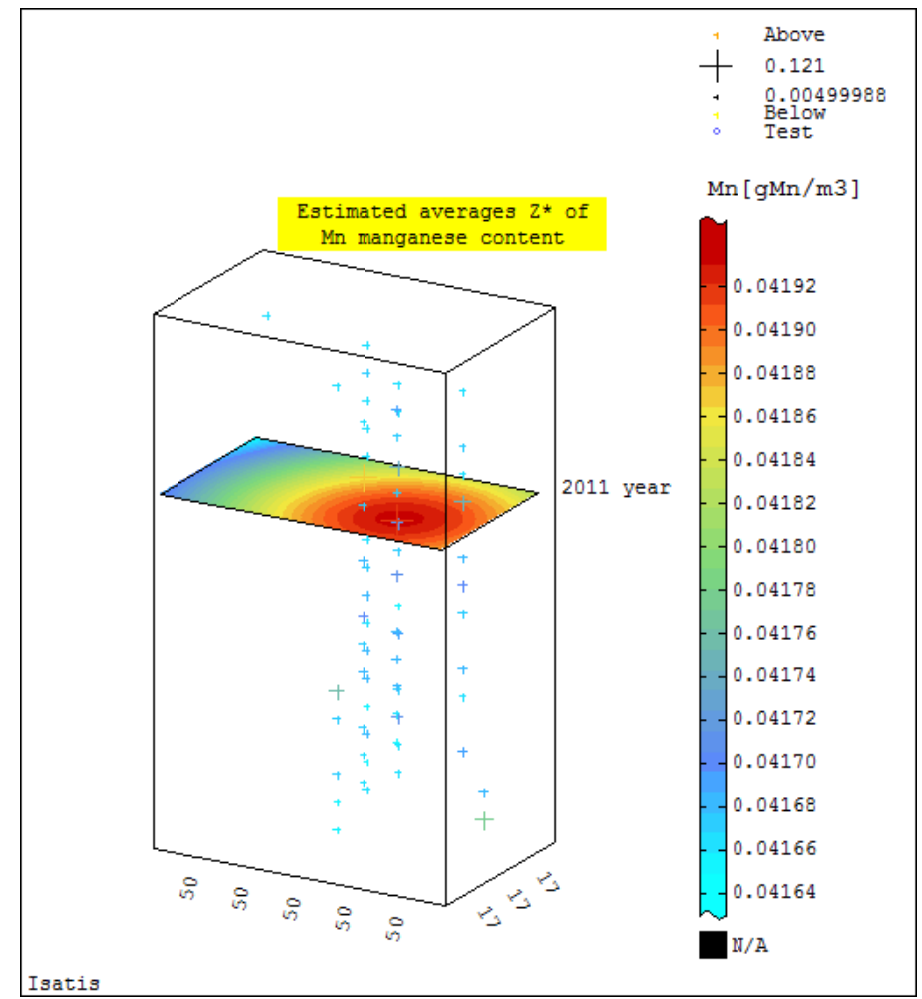

Fig. 15 Raster map (in perspective view) showing distribution of estimated averages $Z^{*}$ of Mn content $\left[\mathrm{gMn} / \mathrm{m}^{3}\right]$ in $\mathrm{Klodzko}$ town water supply system in 2011.

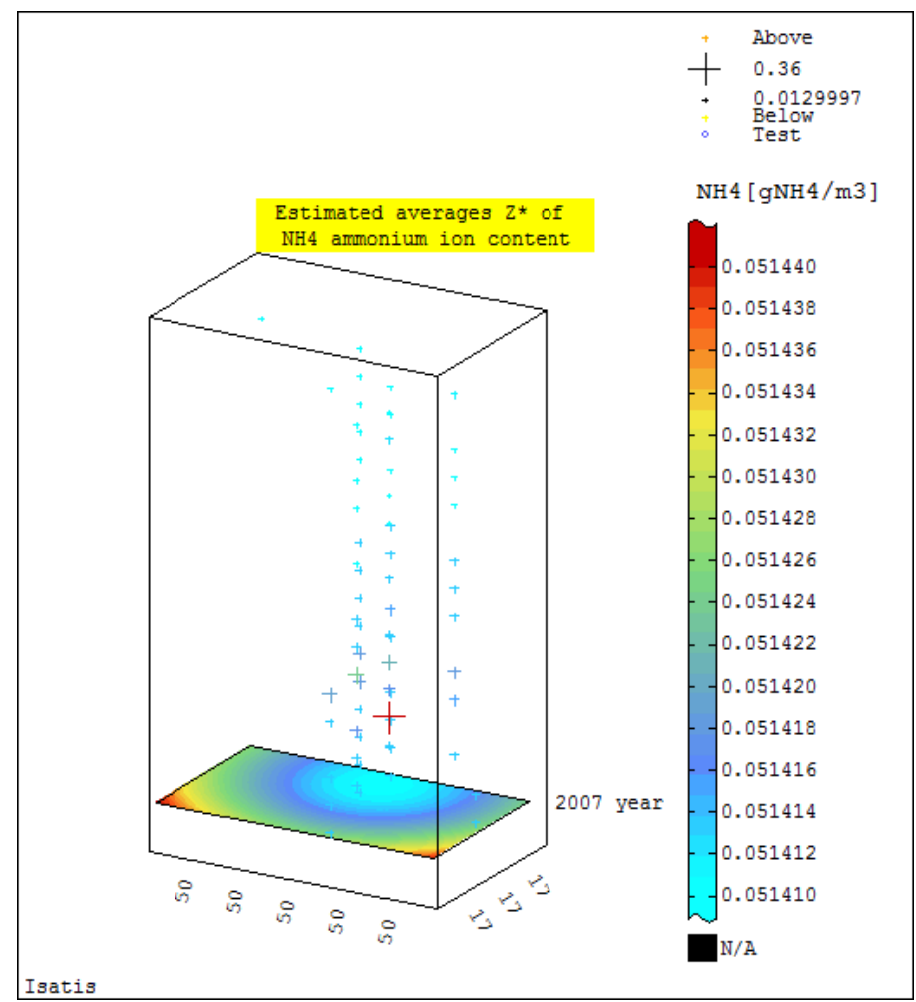

Fig. 16 Raster map (in perspective view) showing distribution of estimated averages $Z^{*}$ of $\left.\mathrm{NH}_{4}^{+} \mathrm{content}^{+} \mathrm{gNH}_{4}^{+} / \mathrm{m}^{3}\right]$ in Klodzko town area water supply system in 2007. 
They occurred in the SW and SE parts of the Klodzko town area. The lowest averages $Z^{*}$ ranged from 0.051410 to $0.051416 \mathrm{gNH}_{4}^{+} / \mathrm{m}^{3}$, covering a considerable area $(2 / 3$ of the Klodzko town area), occurred in the N, E and central part of Klodzko.

In the map for 2010 one could see an increase in averages $Z^{*}$, i.e. the maximum averages $Z^{*}$ ranged from 0.048504 to $0.048509 \mathrm{gNH}_{4}^{+} / \mathrm{m}^{3}$ and formed a small subarea in the SE part (Fig. 17). The minimum averages $Z^{*}$ ranged from 0.048479 to 0.048489 $\mathrm{gNH}_{4}^{+} / \mathrm{m}^{3}$, forming a large subarea (Fig. 17).

In the map for 2011 the maximum averages $Z^{*}$ were observed in the SW and W part of the Klodzko town area, ranging from 0.02082 to $0.02084 \mathrm{gNH}_{4}{ }^{+} / \mathrm{m}^{3}$ (Fig 18). The lowest averages $Z^{*}$, forming a large centre (subarea), ranged from 0.02071 to $0.02074 \mathrm{gNH}_{4}{ }^{+} / \mathrm{m}^{3}$.

\subsection{Block Diagrams of Water Supply System Quality}

\section{Parameters}

The resultant (total) block diagrams (3D Box) showing the distribution of averages $Z^{*}$ of $\mathrm{Fe}, \mathrm{Mn}$ and
$\mathrm{NH}_{4}{ }^{+}$content in the water supply network, reveal certain tendencies in the variation of the parameters characterizing the quality of the water in the years 2007-2011 (Figs. 19-21). In the spatial block diagrams one can see levels of increased and decreased averages $Z^{*}$ of the parameters, corresponding to some of the years.

The year 2007 stood out because of the highest $\mathrm{Fe}$ content averages $Z^{*}$ (in a range of $0.13-0.14 \mathrm{gFe} / \mathrm{m}^{3}$, with an aureola of values: 0.12-0.13 and 0.11-0.12 $\left(\mathrm{gFe} / \mathrm{m}^{3}\right)$ (Fig. 19). A downward trend in averages $Z^{*}$ started in the following years. Beginning with 2007 the changes in averages $Z^{*}$ were distinctly periodic (Fig. 19).

The Mn content parameter showed an opposite behaviour over the years. A variation trend was observed in the years 2007-2011, with a growth towards 2011. The maximum Mn content averages $Z^{*}$ (in range: $0.034-0.038 \mathrm{gMn} / \mathrm{m}^{3}$, with an aureola of values: $0.032-0.034 \mathrm{gMn} / \mathrm{m}^{3}$ ) occurred in 2011 (Fig. 20).

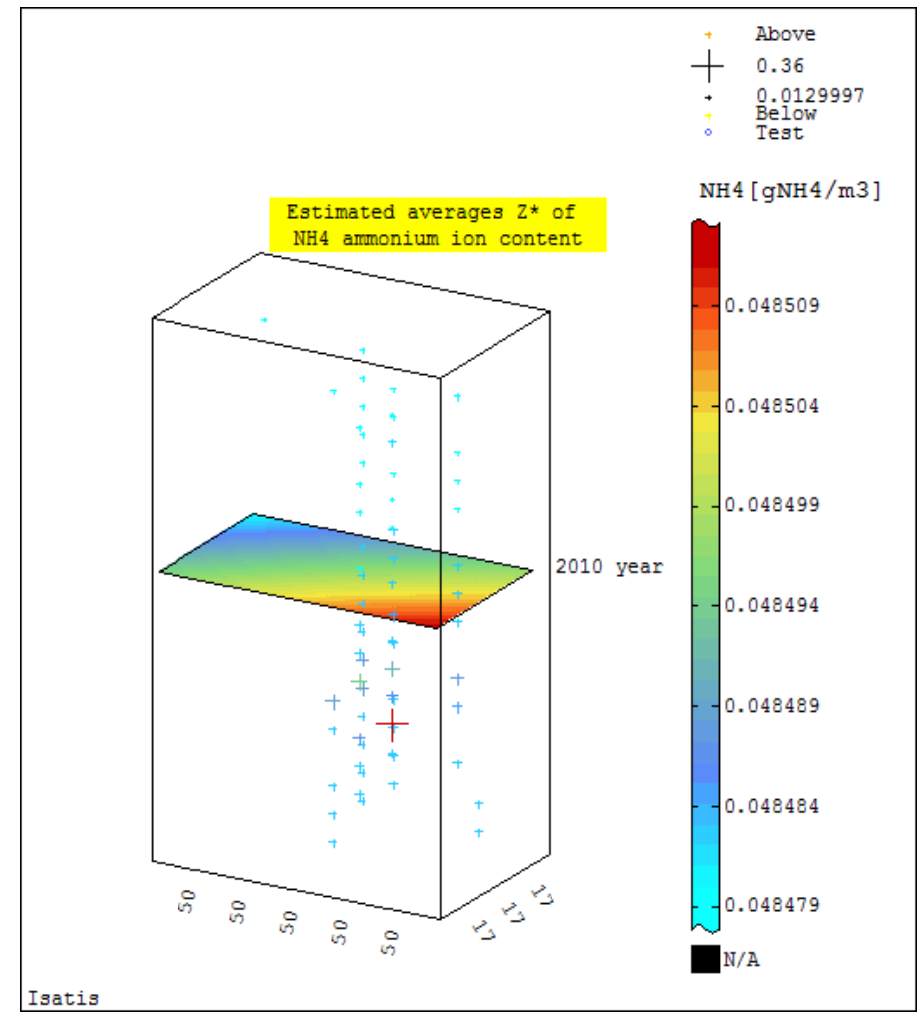

Fig. 17 Raster map (in perspective view) showing distribution of estimated averages $Z^{*}$ of $\mathrm{NH}_{4}^{+}$ammonium ion content $\left[\mathrm{gNH}_{4}{ }^{+} / \mathrm{m}^{3}\right]$ in Klodzko town are water supply system in 2010 . 


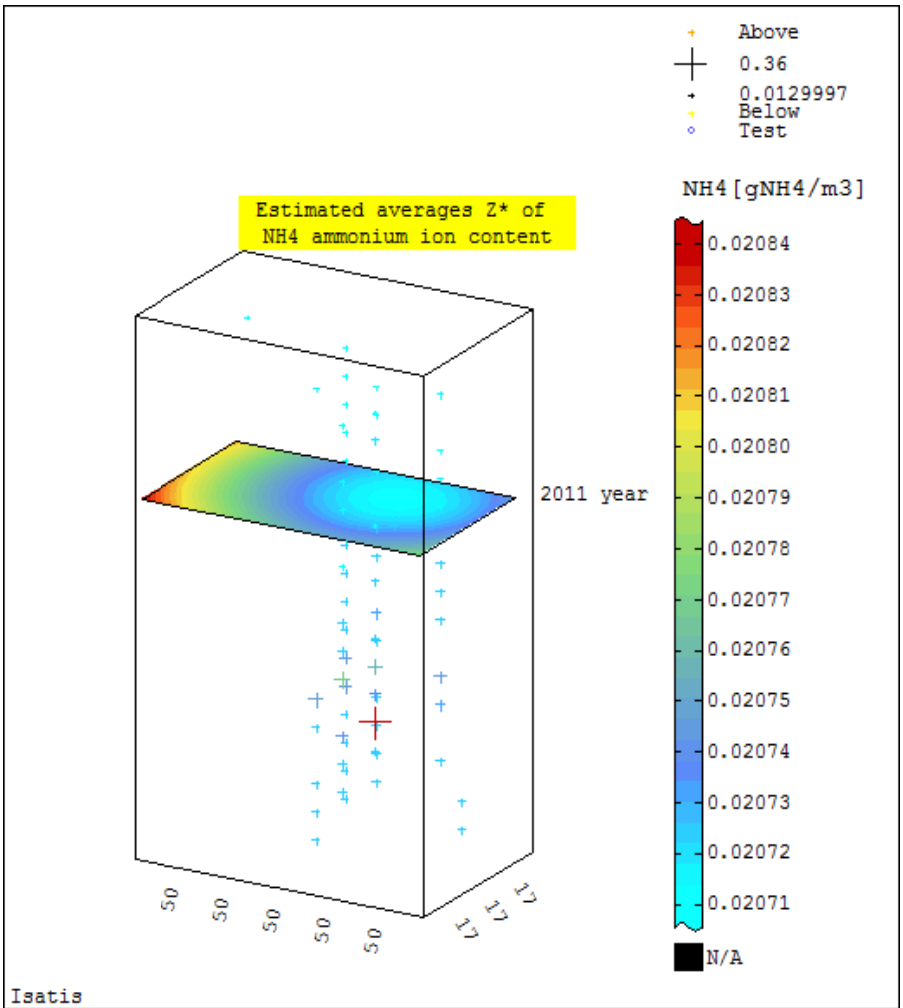

Fig. 18 Raster map (in perspective view) showing distribution of estimated averages $Z^{*} \mathrm{NH}_{4}^{+}$content $\left[\mathrm{gNH}_{4}{ }^{+} / \mathrm{m}^{3}\right]$ in $\mathrm{Klodzko}^{-}$ town area water supply system in 2011.

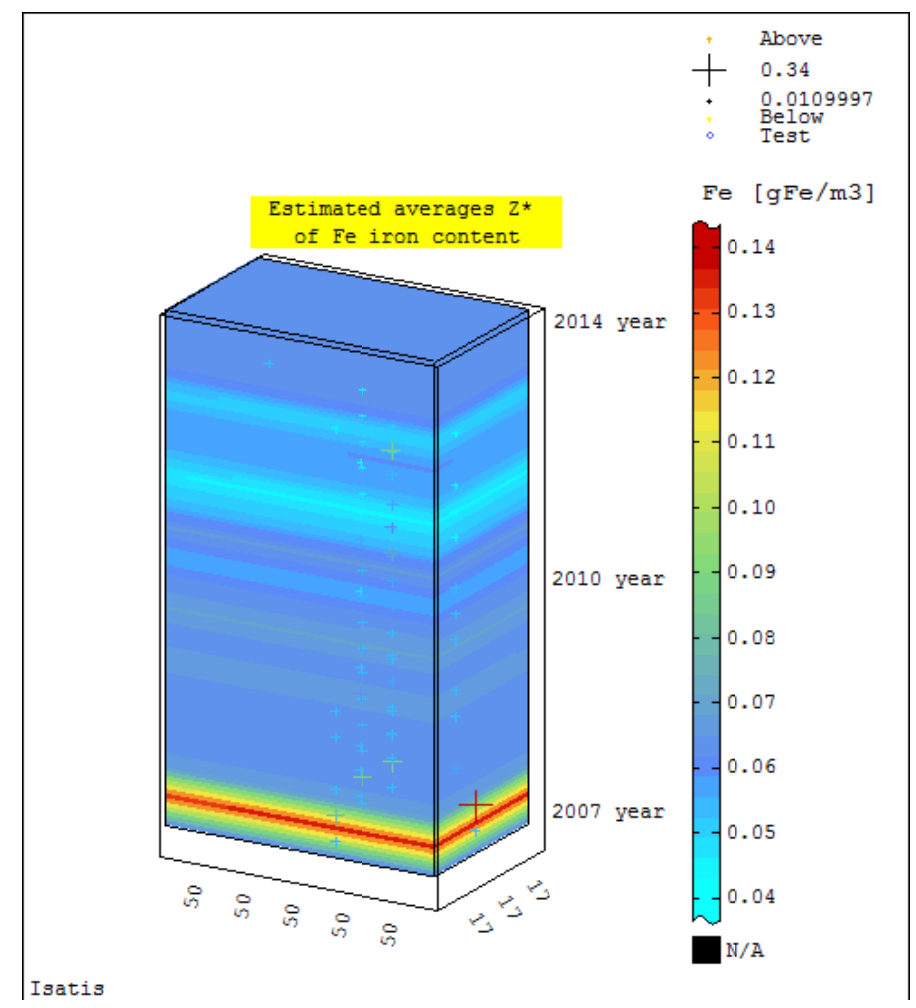

Fig. 19 Block diagram (3D Box) showing distribution of estimated averages $Z^{*}$ of $\mathrm{Fe}$ content $\left[\mathrm{gFe} / \mathrm{m}^{3}\right]$ in water supply system. 
Geostatistical Studies of Space-Temporal Variation in Selected Quality Parameters in Klodzko Water Supply System (SW Part of Poland)

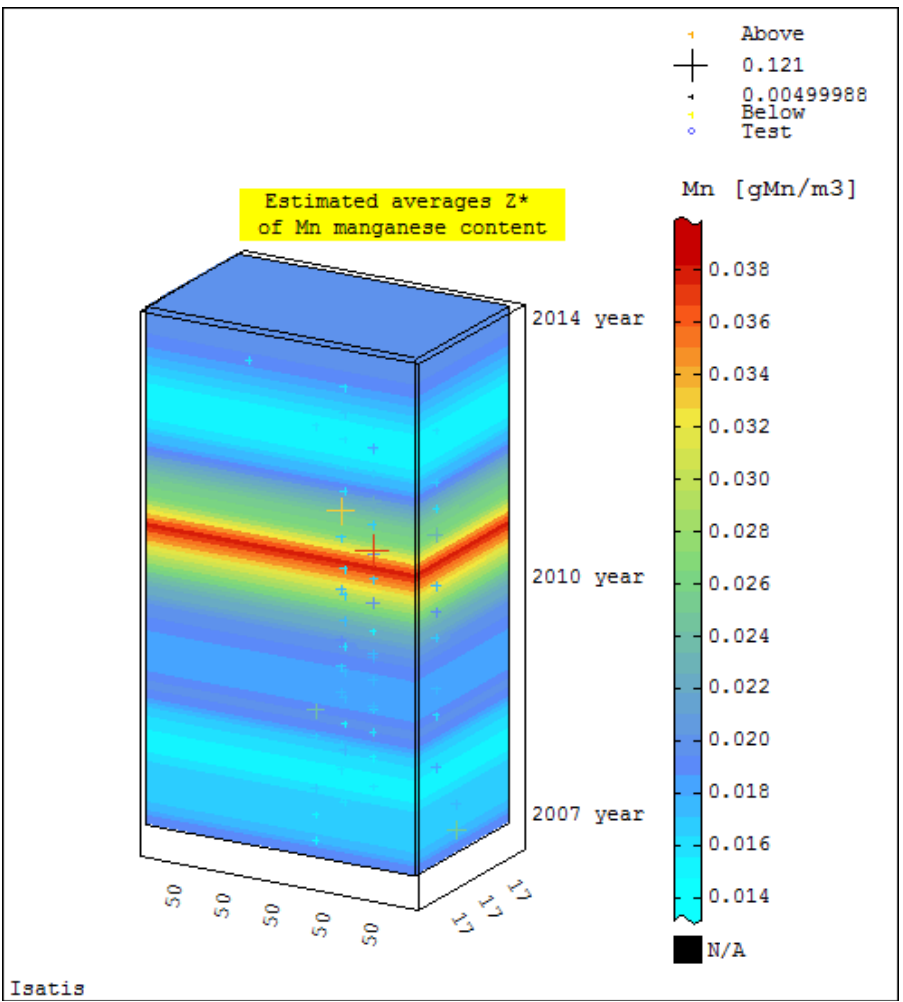

Fig. 20 Block diagram (3D Box) showing distribution of estimated averages $Z^{*}$ of Mn content $\left[\mathrm{gMn} / \mathrm{m}^{3}\right]$ in water supply system.

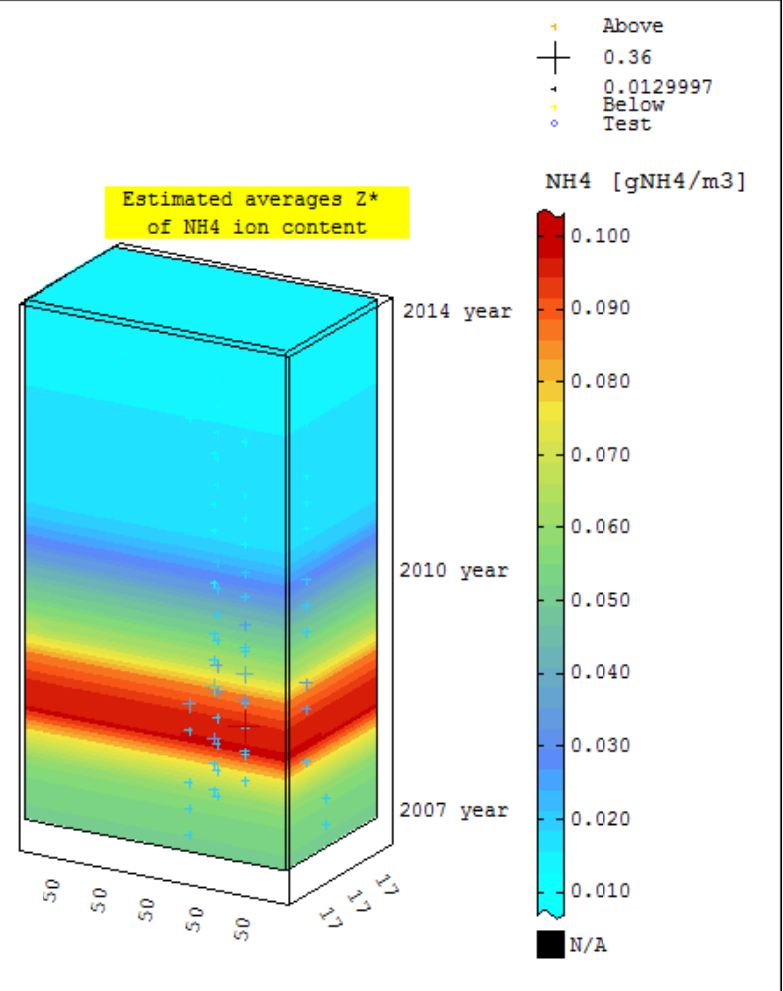

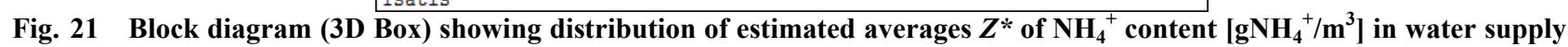
system. 


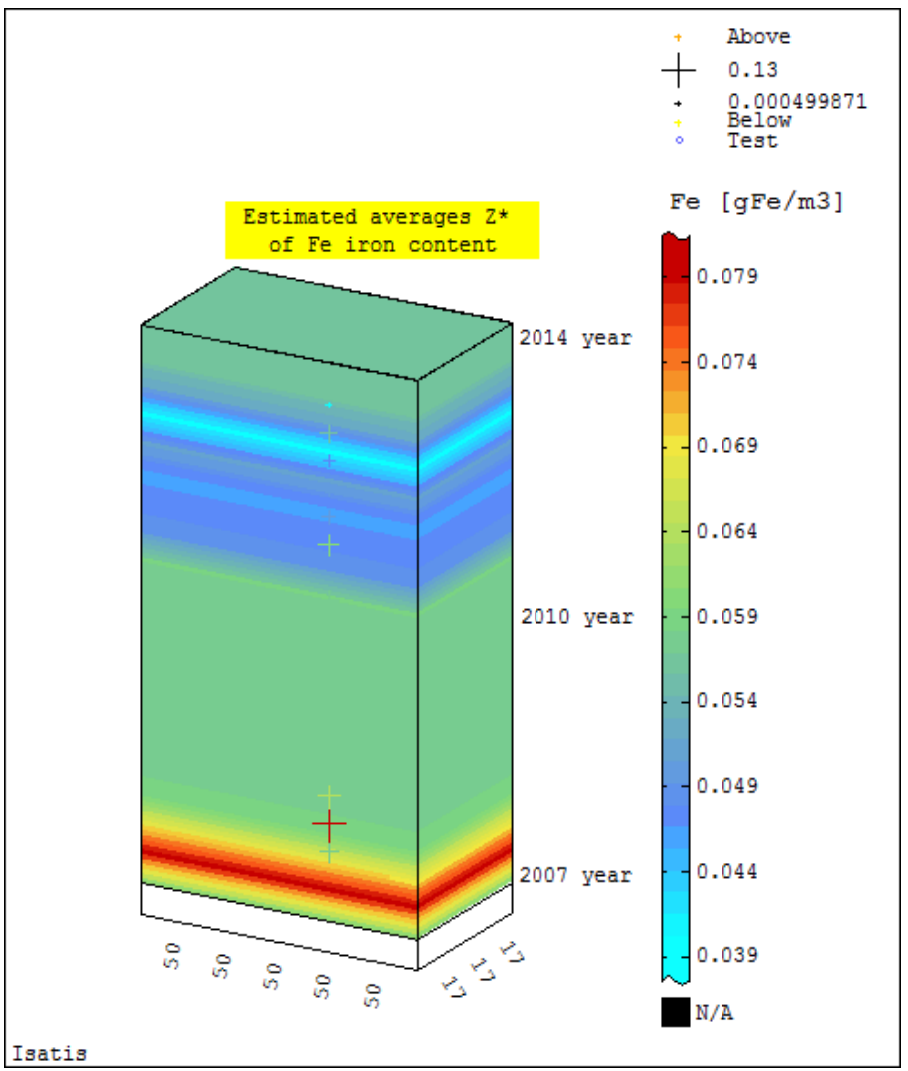

Fig. 22 Block diagram (3D Box) showing distribution of estimated averages $Z^{*}$ of Fe iron content $\left[\mathrm{gFe} / \mathrm{m}^{3}\right]$ in treated water.

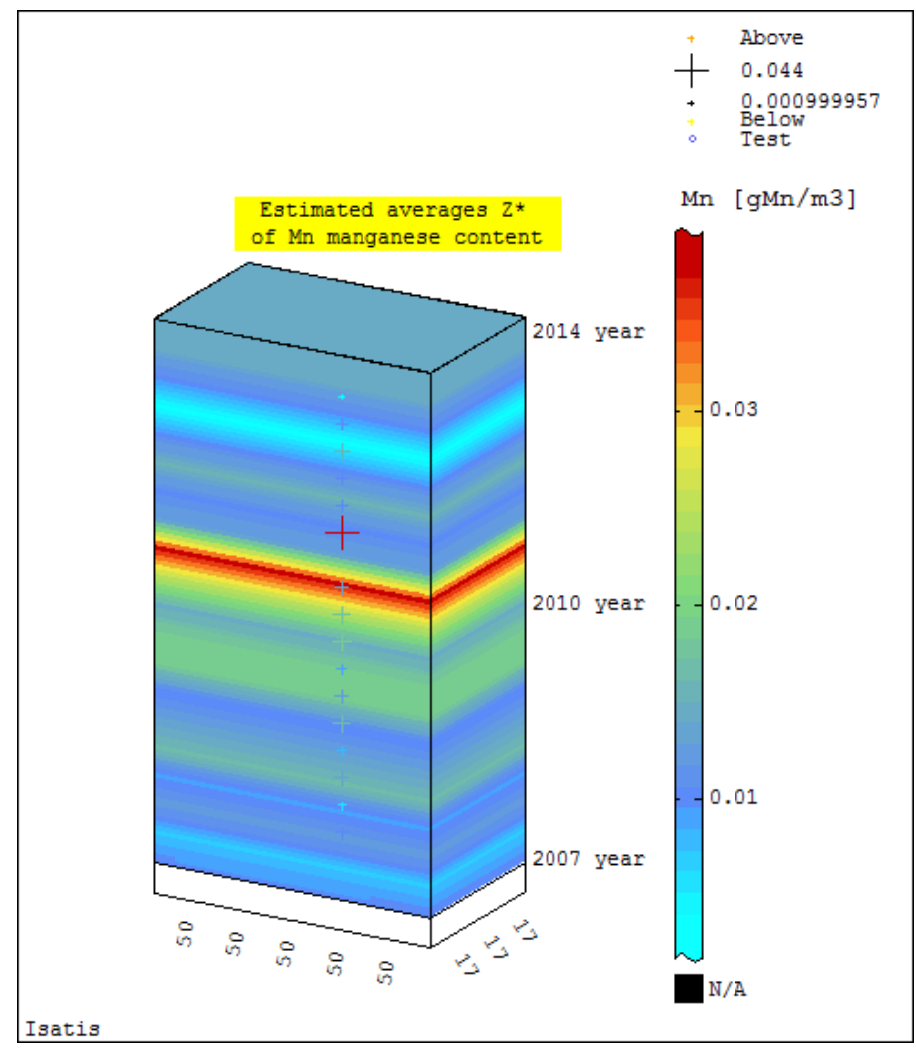

Fig. 23 Block diagram (3D Box) showing distribution of estimated averages $Z^{*}$ of $\mathrm{Mn}$ content $\left[\mathrm{gMn} / \mathrm{m}^{3}\right]$ in treated water. 


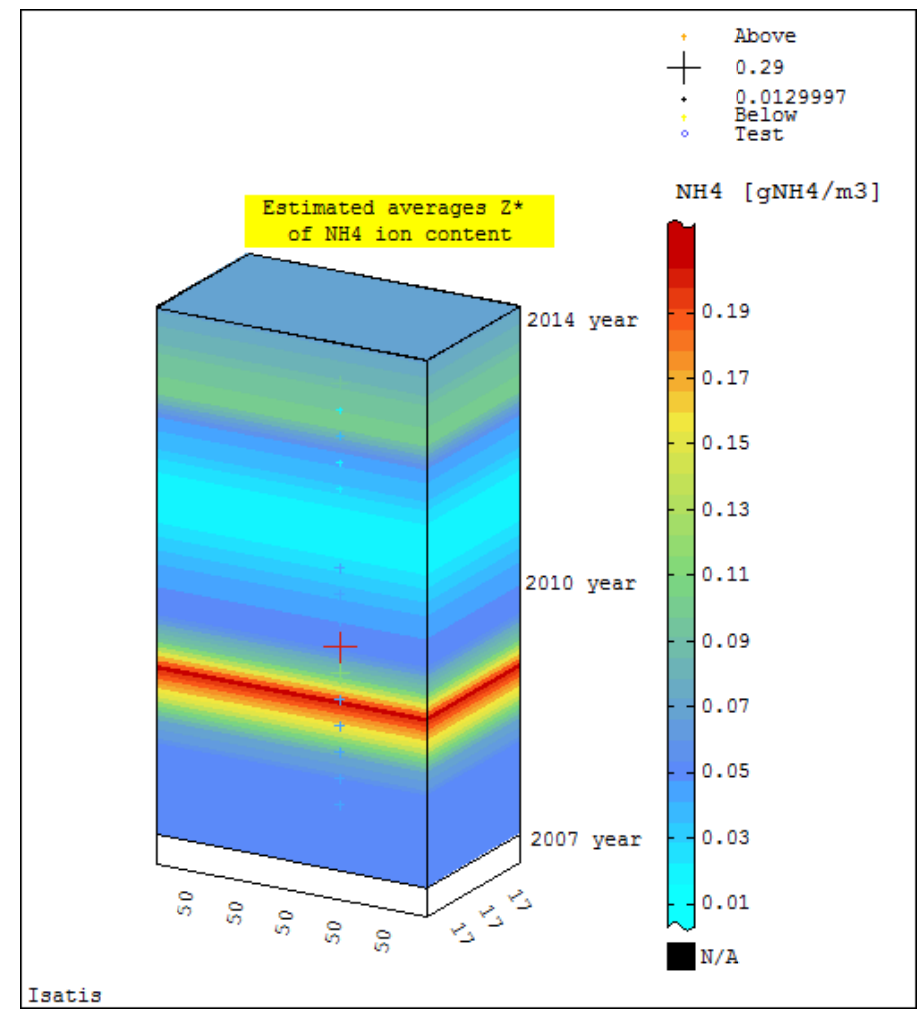

Fig. 24 Block diagram (3D Box) showing distribution of estimated averages $Z^{*}$ of $\mathrm{NH}_{4}^{+}$ion content $\left[\mathrm{gNH}_{4}^{+} / \mathrm{m}^{3}\right]$ in treated water.

The highest $\mathrm{NH}_{4}{ }^{+}$content averages (in a range of: 0.080-0.100 $\mathrm{gNH}_{4}^{+} / \mathrm{m}^{3}$, with an aureola of values: $0.070-0.080 \mathrm{gNH}_{4}^{+} / \mathrm{m}^{3}$ ) occurred in the years 2009-2010 (Fig. 21). A certain periodicity in the variation of $\mathrm{NH}_{4}^{+}$content was observed in the years 2007-2011.

\subsection{Block Diagrams of Treated Water Quality}

\section{Parameters}

Block diagrams of the distribution of treated water quality parameters, plotted in the basis of data from the years 2008-2011 show distinct elevations in the levels of average $\mathrm{Fe}, \mathrm{Mn}$ and $\mathrm{NH}_{4}{ }^{+}$content (Figs. 22-24) in similar years in which they appeared in the block diagrams of the network water quality parameters (Figs. 19-21).

In the block diagram of the averages $Z^{*}$ of $\mathrm{Fe}$ content in treated water for 2007 one could see a level representing a range of averages $Z^{*}$ : 0.074-0.079 $\mathrm{gFe} / \mathrm{m}^{3}$, with an aureola of values reaching 0.069 $\mathrm{gFe} / \mathrm{m}^{3}$ (Fig. 22).
An elevated level of averages $Z^{*}$ of Mn content in treated water, representing a range of values $>0.030 \mathrm{~g}$ $\mathrm{Mn} / \mathrm{m}^{3}$, with an aureola of values: $0.025-0.030 \mathrm{~g}$ $\mathrm{Mn} / \mathrm{m}^{3}$ appeared in the block diagram for 2011 (Fig. 23).

An elevated level of averages $Z^{*}$, ranging from 0.17 to 0.19 and $>0.19 \mathrm{gNH}_{4}^{+} / \mathrm{m}^{3}$, with an aureola of values: 0.15-0.17 $\mathrm{gNH}_{4}^{+} / \mathrm{m}^{3}$ appeared in the block diagram showing the distribution of the averages $Z^{*}$ of $\mathrm{NH}_{4}{ }^{+}$ content in treated water for 2009 (Fig. 24).

\section{Discussion of Results}

The modelling and estimation of the selected water quality parameters of the network water and the treated water for the Klodzko town area were based on a relatively small statistical sample of data. This particularly applies to the size of the treated water data sample. Nevertheless, even the small size of the data sample is sufficient to get a picture of the water quality, i.e. of the changes in $\mathrm{Fe}$ content, $\mathrm{Mn}$ content and $\mathrm{NH}_{4}{ }^{+}$ ion in the treated water over time.

Generally, it is supposed that the quality of both the 
network water and the treated water can be the resultant of the quality of underground water in the Klodzko water intake area, i.e. of the changes in $\mathrm{Fe}$ and $\mathrm{Mn}$ content taking place in the years 1977-2012.

The technique of ordinary kriging was used to estimate $\mathrm{Fe}$ and $\mathrm{Mn}$ content averages $Z^{*}$. However, the shapes of the histograms showing the distribution of the quality parameters, and their skewness coefficients $g_{1}$ seem to indicate that lognormal kriging could have been more useful in this case. The nonsense estimates of values $Z^{*}$ and the underestimation of variance of estimation $\sigma_{k}^{2}$, which are typical of the latter technique, were the reason for using ordinary kriging.

The results of the presented spatial analyses should be enriched with calculations based on the content of the databases, extended with the results of the chemical analyses of the $\mathrm{Fe}, \mathrm{Mn}$ and $\mathrm{NH}_{4}{ }^{+}$content in the samples of the treated water and the Kłodzko water pipe network water carried out in the years 2012-2015.

\section{Conclusions}

Thanks to the developed (3D) geostatistical hydrogeochemical model of the variation in the water quality parameters in the Klodzko town water supply network it was possible to characterize the variation tendencies and their regularity over the years 2007-2011.

The variation in iron $(\mathrm{Fe})$ content, manganese $(\mathrm{Mn})$ content and ammonium ion $\left(\mathrm{NH}_{4}{ }^{+}\right)$content in treated water and in the water supply system was accurately modelled through a structural analysis of the variation in the water quality parameters, consisting in applying the directional variogram function and determining directional semivariograms along the time axis (the years 2007-2011), and through the subsequent use of ordinary kriging.

The results of the geo-statistical studies show that, besides heavy metals (cadmium $\mathrm{Cd}$ and mercury $\mathrm{Hg}$ ) content, the basic water quality parameters-first Mn content, then $\mathrm{Fe}$ content (in both network water and raw (mixed) water) and to a lesser degree $\mathrm{NH}_{4}{ }^{+}$ion content-should be regarded with special interest. Most often Mn content and Fe content exceeded the levels permissible for these elements.

Changes in the Fe content and Mn content are more apparent. The true character of their variation for the network water could have been better traced if a longer period had been analyzed, as indicated by the semivariograms of the content of the elements in the underground water.

Elevated levels of averages $Z^{*}$ of the investigated water quality parameters in network water and treated water occurred in certain years ( $\mathrm{Fe}$ content in 2007, $\mathrm{NH}_{4}{ }^{+}$content in 2009-2010, Mn content in 2011). For both kinds of water (the network water and the treated water) the elevated levels were observed in the same years.

In the analyzed relatively short period (2007-2011) towards 2011 a clearly downward trend in Fe content in the network water, accompanied by a tendency towards periodic variation, became clearly apparent. The Mn content in the network water was characterized by an opposite behaviour, showing an upward trend in its variation towards 2011. A similar tendency was observed in the case of ammonium ion $\left(\mathrm{NH}_{4}{ }^{+}\right)$content, with a clear growth from 2007 to 2010 .

In the years 2007-2011 the maximum values of Mn content, $\mathrm{Fe}$ content and $\mathrm{NH}_{4}{ }^{+}$content in the network water would occur in different parts of the Klodzko town water supply system area, but mostly they would appear in the SW, S and W parts.

The fact that the analyzed period of time was short, whereby the size of the sample taken into account in the spatial analyses was not rich (particularly small in the case of the treated water), and that the geochemical nature of the elements in the water was different and affected the obtained picture of the variation.

\section{Acknowledgments}

The author of this paper has been expressing her special thanks to the Representatives of Wodociagi Kłodzkie (Klodzko Water Board) for making of an 

Parameters in Klodzko Water Supply System (SW Part of Poland)

available data on the chemical analyses of network and treated water of samples in Klodzko water supply system carried out in the years 2007-2011 and the 2008-2011.

\section{References}

[1] Namysłowska-Wilczyńska, B. 2012. Hydrogeochemical Model for Underground Water in Take Area in Kłodzko (in Polish). SPR series report no. 1/2012.

[2] Namysłowska-Wilczyńska, B. 2013. “Geostatistical Hydrogeochemical 3D Model for Kłodzko Underground Water Intake Area. Part I. Estimation of Basic Statistics on Quality Parameters of Underground Waters." Studia Geotechnica et Mechanica 35 (1): 157-81.

[3] Namysłowska-Wilczyńska, B. 2013. "Estimation of Underground Water Quality Parameters for the Water Intake Area near Kłodzko by Means of Ordinary Kriging (in Polish)." In Proceedings of the $X X$ KK KOWBAN" 2013 National Conference "Computer Support of Research", 215-25.

[4] Namysłowska-Wilczyńska, B. 2014. “Geostatistical Studies of Space-Time Variation in Underground Water Quality Parameters in Klodzko Water Intake Area (SW Part of Poland)." In Proceedings of the 10th Conference on Geostatistics for Environmental Applications, 133-4.

[5] Biedroń, I., Świderska-Bróż, M., Traczewska, T., Trusz-Zdybek, A., Namysłowska-Wilczyńska, B., and Wolska, M. 2013. "Preliminary Assessment of the Quality of Underground Waters in a Selected Area of the Kłodzko Valley (in Polish)." Instal, Teoriai Praktyka w Instalacjach 6 (341): 41-4.

[6] Mądrala, M. 2001. "Hydrogeochemical Valorization of
Environments of River Valleys for the Needs of Underground Waters Exploitation." In Proceedings of the Współczesne Problemy Hydrogeologii, 357-64.

[7] Armstrong, M. 1998. Basic Linear Geostatistics. Berlin: Springer.

[8] Isaaks, E. H., and Srivastava, R. M. 1989. An Introduction to Applied Geostatistics. N.Y.: OUP.

[9] Namysłowska-Wilczyńska, B. 2006. Geostatistics. Theory and Applications. Monography. Wrocław: Wroclaw University of Technology.

[10] Wackernagel, H. 1998. Multivariate Geostatistics: an Introduction with Applications. 2nd edition. Berlin: Springer, 291.

[11] Bicz, W., Konieczna, M., and Zilbert, A. 1999. "Water Treatment with Dynasand Filters: A Case Study." Ochrona Środowiska 4 (75): 33-6.

[12] Regulation of Ministry of Health. Ordinance of Polish Minister of Health of 29 March 2007 on the Quality of Water Intended for Human Consumption. Dz. U. No. 61, pos. 417, as amended.

[13] Regulation of Ministry of Health. 2010. Amending the Regulation on the Quality of Water Intended for Human Consumption. Dz. U. no 72, Pos. 466.

[14] Mazowiecki, T. 2015. "Removal of Iron and Manganese." Technical-Commercial Firm. Accessed March 14, 2015 and July 15, 2015. Http://www.wodpol.com.pl.

[15] Namysłowska-Wilczyńska, B. 2015. "Geostatistical Characteristic of Space-Time Variation in Quality Parameters in Klodzko Water Supply System (SW Part of Poland)." Presented at the European Geosciences Union General Assembly, Vienna, Austria.

[16] Water Treatment Station-Wodociagi Kłodzkie, Klodzko, Lower Silesia, Sp. z o.o. Accessed February 15, 2015 and July 15, 2015. Http://www.wodociagi.klodzko.pl. 